\title{
Satellite-derived methane hotspot emission estimates using a fast data-driven method
}

\author{
Michael Buchwitz ${ }^{1}$, Oliver Schneising ${ }^{1}$, Maximilian Reuter ${ }^{1}$, Jens Heymann ${ }^{1}$, Sven Krautwurst ${ }^{1}$, \\ Heinrich Bovensmann $^{1}$, John P. Burrows ${ }^{1}$, Hartmut Boesch ${ }^{2,3}$, Robert J. Parker ${ }^{2,3}$, Peter Somkuti ${ }^{2,3}$, \\ Rob G. Detmers ${ }^{4}$, Otto P. Hasekamp ${ }^{4}$, Ilse Aben ${ }^{4}$, André Butz ${ }^{5,6}$, Christian Frankenberg ${ }^{7,8}$, and Alexander J. Turner ${ }^{9}$ \\ ${ }^{1}$ Institute of Environmental Physics (IUP), University of Bremen, Bremen, Germany \\ ${ }^{2}$ Earth Observation Science, University of Leicester, Leicester, UK \\ ${ }^{3}$ NERC National Centre for Earth Observation, Leicester, UK \\ ${ }^{4}$ SRON Netherlands Institute for Space Research, Utrecht, the Netherlands \\ ${ }^{5}$ Karlsruhe Institute of Technology (KIT), Karlsruhe, Germany \\ ${ }^{6}$ Ludwig-Maximilians-Universität (LMU), Munich, Germany \\ ${ }^{7}$ Division of Geological and Planetary Sciences, California Institute of Technology, California, Pasadena, CA, USA \\ ${ }^{8}$ Jet Propulsion Laboratory, Pasadena, CA, USA \\ ${ }^{9}$ School of Engineering and Applied Sciences, Harvard University, Cambridge, MA, USA
}

Correspondence to: Michael Buchwitz (michael.buchwitz@iup.physik.uni-bremen.de)

Received: 22 August 2016 - Discussion started: 24 August 2016

Revised: 8 February 2017 - Accepted: 15 April 2017 - Published: 9 May 2017

\begin{abstract}
Methane is an important atmospheric greenhouse gas and an adequate understanding of its emission sources is needed for climate change assessments, predictions, and the development and verification of emission mitigation strategies. Satellite retrievals of near-surface-sensitive columnaveraged dry-air mole fractions of atmospheric methane, i.e. $\mathrm{XCH}_{4}$, can be used to quantify methane emissions. Maps of time-averaged satellite-derived $X_{\mathrm{CH}_{4}}$ show regionally elevated methane over several methane source regions. In order to obtain methane emissions of these source regions we use a simple and fast data-driven method to estimate annual methane emissions and corresponding $1 \sigma$ uncertainties directly from maps of annually averaged satellite $\mathrm{XCH}_{4}$. From theoretical considerations we expect that our method tends to underestimate emissions. When applying our method to high-resolution atmospheric methane simulations, we typically find agreement within the uncertainty range of our method (often $100 \%$ ) but also find that our method tends to underestimate emissions by typically about $40 \%$. To what extent these findings are model dependent needs to be assessed. We apply our method to an ensemble of satellite $\mathrm{XCH}_{4}$ data products consisting of two products from SCIAMACHY/ENVISAT and two products from TANSO-
\end{abstract}

FTS/GOSAT covering the time period 2003-2014. We obtain annual emissions of four source areas: Four Corners in the south-western USA, the southern part of Central Valley, California, Azerbaijan, and Turkmenistan. We find that our estimated emissions are in good agreement with independently derived estimates for Four Corners and Azerbaijan. For the Central Valley and Turkmenistan our estimated annual emissions are higher compared to the EDGAR v4.2 anthropogenic emission inventory. For Turkmenistan we find on average about $50 \%$ higher emissions with our annual emission uncertainty estimates overlapping with the EDGAR emissions. For the region around Bakersfield in the Central Valley we find a factor of 5-8 higher emissions compared to EDGAR, albeit with large uncertainty. Major methane emission sources in this region are oil/gas and livestock. Our findings corroborate recently published studies based on aircraft and satellite measurements and new bottom-up estimates reporting significantly underestimated methane emissions of oil/gas and/or livestock in this area in EDGAR. 


\section{Introduction}

Methane $\left(\mathrm{CH}_{4}\right)$ is the second most important human-emitted greenhouse gas and increases in its atmospheric abundance contribute significantly to global warming (IPCC, 2013). Accurate knowledge of its sources and sinks and the origins of any changes are needed for the accurate prediction of future climate change, the attribution of change, and the development of mitigation strategies. However, our current knowledge about the various natural and anthropogenic methane sources and sinks is inadequate (e.g. Rigby et al., 2008; Dlugokencky et al., 2009; IPCC, 2013; Kirschke et al., 2013; Houweling et al., 2014, 2017; Nisbet et al., 2014; Jeong et al., 2014; Alexe et al., 2015; Jacob et al., 2016; Schaefer et al., 2016; Miller and Michalak et al., 2016).

Near-surface-sensitive satellite observations of atmospheric methane have been used in recent years to obtain quantitative information on methane emissions (e.g. Alexe et al., 2015; Bergamaschi et al., 2007, 2009, 2013; Bloom et al., 2010; Turner et al., 2015, 2016; Fraser et al., 2013; Monteil et al., 2013; Cressot et al., 2014; Wecht et al., 2014a, b; Kort et al., 2014; Jacob et al., 2016; Houweling et al., 2017). Nevertheless, there are still many important aspects which need further investigation. For example, the recent renewed methane growth (e.g. Houweling et al., 2014) needs to be unambiguously explained and better knowledge of evolving man-made emission sources (e.g. Schneising et al., 2014) is required.

Several important issues for the future management and mitigation of methane emissions are not yet resolved adequately, e.g. the methods to verify emission inventories and reported emissions per region (country down to city scale) (e.g. Ciais et al., 2014). The latter aspect was studied in the development of the CarbonSat mission (Bovensmann et al., 2010; Velazco et al., 2011; Buchwitz et al., 2013; Pillai et al., 2016) for $\mathrm{CO}_{2}$ using performance assessments based on simulated satellite observations (ESA, 2015) but so far only few studies have been published using real satellite data (e.g. Wecht et al., 2014a; Turner et al., 2015, 2016, for USA methane emissions). In this study we report an approach to use satellite methane retrievals to estimate methane emissions of two countries, Azerbaijan and Turkmenistan, which are both important oil- and gas-producing countries, and also apply our method to two regions in the USA.

This paper is structured as follows: in Sect. 2 we introduce briefly the satellite data which have been used in this study. In Sect. 3 we describe the analysis method developed to derive methane emissions of (relatively) well-localized areas from time-averaged satellite $\mathrm{XCH}_{4}$ retrievals. The results as obtained from the satellite retrievals are presented and discussed in Sect. 4 and the summary and conclusions are given in Sect. 5.

\section{Satellite data}

During recent years the retrieval of near-surface-sensitive column-averaged dry-air mole fractions of atmospheric methane $\left(\mathrm{CH}_{4}\right)$ and carbon dioxide $\left(\mathrm{CO}_{2}\right)$, i.e. $\mathrm{XCH}_{4}$ and $\mathrm{XCO}_{2}$, from the satellite sensors SCIAMACHY (Burrows et al., 1995; Bovensmann et al., 1999) on board ENVISAT and TANSO-FTS on board GOSAT (Kuze et al., 2009, 2016) significantly evolved and improved (e.g. Buchwitz et al., 2015, 2016a, b; Butz et al., 2011; Dils et al., 2014; Frankenberg et al., 2011; Parker et al., 2011, 2015; Schneising et al., 2011, 2012, 2014; Yoshida et al., 2013).

For this study we use the latest data sets of $\mathrm{XCH}_{4}$ retrievals from SCIAMACHY and GOSAT as generated by different research teams of the GHG-CCI project (Buchwitz et al., 2015) of the European Space Agency (ESA) Climate Change Initiative (CCI; Hollmann et al., 2013). The four satellite $\mathrm{XCH}_{4}$ products used for this study are publicly available and have been obtained from the GHG-CCI website (http://www.esa-ghg-cci.org; "latest data sets" refers to data access mid-2016; new versions are in preparation and are planned to be released in March 2017), where also detailed documentation is available (e.g. Algorithm Theoretical Basis Documents (ATBDs), Comprehensive Error Characterization Reports (CECRs), Product Validation and Intercomparison Report (PVIR); Buchwitz et al., 2016a).

Table 1 presents an overview about the four $\mathrm{XCH}_{4}$ satellite data products used in this study. As can be seen, these comprise two SCIAMACHY $\mathrm{XCH}_{4}$ data products retrieved with the WFMD (Buchwitz et al., 2000; Schneising et al., 2011, 2012, 2013) and IMAP (Frankenberg et al., 2005, 2006, 2008a, b, 2011) retrieval algorithms, i.e. the GHG-CCI products CH4_SCI_WFMD and CH4_SCI_IMAP. In addition, we use the two GOSAT products CH4_GOS_OCPR (Parker et al., 2011, 2015) and CH4_GOS_SRFP (Butz et al., 2011, 2012). The $\mathrm{XCH}_{4}$ "full physics" (FP) retrieval algorithm used to generate the latter product is also known as "RemoTeC" and the algorithm to generate the CH4_GOS_OCPR product is the University of Leicester $\mathrm{XCH}_{4}$ " $\mathrm{CO}_{2}$ proxy" (PR) algorithm. The two SCIAMACHY $\mathrm{XCH}_{4}$ algorithms are also "proxy" algorithms. Here, the $\mathrm{XCH}_{4}$ product is obtained by computing the ratio of the retrieved methane column and the simultaneously retrieved $\mathrm{CO}_{2}$ column multiplied by a correction factor for $X \mathrm{CO}_{2}$ variations using a $\mathrm{CO}_{2}$ model (Frankenberg et al., 2005). The FP algorithm does not require this $\mathrm{CO}_{2}$ correction as $\mathrm{XCH}_{4}$ is retrieved directly, which is an advantage compared to PR algorithms. However, each algorithm has different strengths and weaknesses. An advantage of the $\mathrm{XCH}_{4} \mathrm{PR}$ algorithms is that atmospheric light-path-related errors arising from imperfect knowledge of wavelength-dependent scattering by aerosols and clouds largely cancel in the $\mathrm{CH}_{4}$-to- $\mathrm{CO}_{2}$ column ratio. This source of error is consequently less of a problem for PR algorithms compared to FP algorithms, which require more complex radiative transfer modelling and stricter quality filtering com- 
pared to the PR products (see also Schepers et al., 2012, for PR and FP algorithms and corresponding data products as well as Buchwitz et al., 2015, 2016a, b). As a consequence, FP data products are typically much sparser compared to PR products but are independent of the $\mathrm{CO}_{2}$ model used.

The latest validation results for the GHG-CCI $X \mathrm{CH}_{4}$ data products are presented and discussed in Buchwitz et al. (2016a). These were obtained by comparing the satellite retrievals with ground-based $\mathrm{XCH}_{4}$ observations of the Total Carbon Column Observing Network, TCCON (Wunch et al., 2011, 2015). As shown in Buchwitz et al. (2016a), the GOSAT $\mathrm{XCH}_{4}$ products are very stable, i.e. do not show any significant trend of the difference with respect to TCCON. For SCIAMACHY the situation is more complex due to potential detector problems in later years resulting in larger noise but also bias issues, depending on retrieval algorithm. For example, as shown in Buchwitz et al. (2016a), the IMAP product suffers from a bias (a discontinuity in $X \mathrm{CH}_{4}$ ) in 2010. For this reason, we decided to restrict the use of the SCIAMACHY products in this study to the period 2003-2009. The achieved single measurement precision (random error) for SCIAMACHY $\mathrm{XCH}_{4}$ is in the range 30$80 \mathrm{ppb}(2-5 \%)$ depending on time period and product and approximately $16 \mathrm{ppb}(\sim 1 \%)$ for GOSAT. Systematic errors ("relative accuracy" or "relative bias") are around 10$15 \mathrm{ppb}(\sim 0.6 \%)$ for SCIAMACHY and approximately $6 \mathrm{ppb}$ $(\sim 0.3 \%)$ for GOSAT.

Annual average composite maps of the four data products are shown in Figs. 1 and 2. Figure 1 shows year 2004 SCIAMACHY $\mathrm{XCH}_{4}$ at $0.5^{\circ} \times 0.5^{\circ}$ resolution as retrieved using the WFM-DOAS (WFMD) algorithm (Schneising et al., 2011). Also shown are zooms for the three target regions investigated in this study. Figure 2 shows year 2004 SCIAMACHY IMAP-DOAS (IMAP) $\mathrm{XCH}_{4}$ and year 2010 $\mathrm{XCH}_{4}$ as retrieved using the two GOSAT algorithms. As can be seen, the spatial coverage of the GOSAT products is quite sparse. A single GOSAT observation requires more time (4s) compared to a SCIAMACHY observation (typically $0.25 \mathrm{~s}$ for the spectral regions relevant for this study) and, therefore, GOSAT provides less observations in a given time period than SCIAMACHY. However, the GOSAT ground-pixel size is smaller ( $10 \mathrm{~km}$ diameter) compared to SCIAMACHY (approximately $30 \mathrm{~km}$ along track times $60 \mathrm{~km}$ across track), which results in a higher fraction of cloud-free observations for GOSAT. Furthermore, SCIAMACHY is in nadir (down-looking) observation mode only about $50 \%$ of the time. Overall the total number of quality filtered observations as contained in the data products is larger for SCIAMACHY compared to GOSAT. Furthermore, the spatial sampling of GOSAT comprises non-contiguous ground pixels, which results in large data gaps (even in yearly averages). Consequently, GOSAT is typically (i.e. in normal observation mode) not optimal for small-scale hotspot applications but, as shown in this paper, GOSAT provides results for the selected source regions which agree reasonably well with the

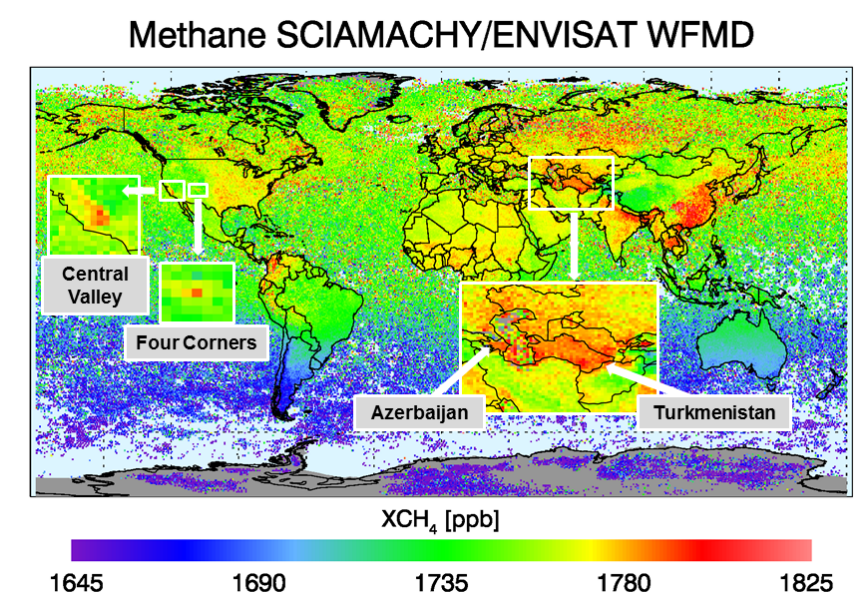

Figure 1. Year 2004 SCIAMACHY WFMD $\mathrm{XCH}_{4}$ at $0.5^{\circ} \times 0.5^{\circ}$ resolution. The source regions studied in this paper are indicated: Central Valley (California, USA), the Four Corners area (southwestern USA), Azerbaijan, and Turkmenistan.

results obtained using SCIAMACHY (e.g. in terms of mean value and scatter of the resulting annual emission estimates). In the remainder of this paper we focus on obtaining methane emission estimates for the source areas shown in Fig. 1.

\section{Analysis method}

In this section we describe the analysis method used to obtain methane emission estimates for source regions such as those shown in Fig. 1, i.e. for regions showing elevated methane relative to their surrounding area in time-averaged satellitederived $\mathrm{XCH}_{4}$ maps.

The satellite $\mathrm{XCH}_{4}$ input data used in this study are the GHG-CCI Level 2 (i.e. individual ground-pixel observations) data products as described in the previous section (see also Table 1). The first step in the analysis comprises gridding (averaging) these products using a regular latitude-longitude grid (here: $0.5^{\circ} \times 0.5^{\circ}$ ) to obtain maps of annual averages (see Figs. 1 and 2). These mapped $\mathrm{XCH}_{4}$ products are then used in this study for further analysis.

The second step comprises the definition of a source region and a surrounding (or background) region. The latter is an extended region surrounding the source region (specific examples are shown in Sect. 4).

The third step comprises the determination of the methane enhancement over the source region relative to its surrounding area, $\triangle X \mathrm{XH}_{4}$. This methane enhancement is computed by subtracting the mean value of $X_{\mathrm{CH}_{4}}$ in the surrounding region from the mean $\mathrm{XCH}_{4}$ value over the source region.

To reduce potential effects related to a location-dependent weighting of tropospheric and stratospheric contributions on $\mathrm{XCH}_{4}$ (as mean stratospheric $\mathrm{CH}_{4}$ mixing ratios are typically lower compared to tropospheric mixing ratios) we apply a correction called "elevation correction" (EC) similar to that 
Table 1. Overview of the satellite $\mathrm{XCH}_{4}$ data products used.

\begin{tabular}{|c|c|c|c|c|c|}
\hline Product & Sensor & Algorithm & Version & Institute & References \\
\hline CH4_SCI_IMAP & $\begin{array}{l}\text { SCIAMACHY } \\
\text { on ENVISAT }\end{array}$ & IMAP-DOAS (IMAP) & 7.1 & JPL/SRON & $\begin{array}{l}\text { Frankenberg et al. (2005, } \\
2006,2008 \mathrm{a}, \mathrm{b}, 2011)\end{array}$ \\
\hline CH4_GOS_OCPR & $\begin{array}{l}\text { TANSO-FTS } \\
\text { on GOSAT }\end{array}$ & UoL-Proxy & 6.0 & Univ. Leicester & Parker et al. (2011) \\
\hline
\end{tabular}

described in Kort et al. (2014) and Turner et al. (20160 (and implicitly also applied in Schneising et al., 2014). The purpose is to correct for satellite $\mathrm{XCH}_{4}$ variations due to variations of surface elevation/pressure and tropopause height. The corrected $\mathrm{XCH}_{4}$ is obtained from the original satellite $X_{\mathrm{CH}_{4}}$ retrievals by adding $7 \mathrm{ppb}$ per $1 \mathrm{~km}$ surface elevation increase relative to mean sea level. For surface elevation we use a surface elevation map (also $0.5^{\circ} \times 0.5^{\circ}$ ) calculated using the GTOPO30 digital elevation model (DEM) (obtained from https://lta.cr.usgs.gov/GTOPO30). The value of $7 \mathrm{ppb} \mathrm{km}^{-1}$ has been obtained by fitting a linear function to pairs of uncorrected original $\mathrm{XCH}_{4}$ and corresponding surface elevation. We found that the exact value depends somewhat on region, time period, and satellite data product but is typically within $7 \pm 2 \mathrm{ppb} \mathrm{km}^{-1}$. We found that applying EC typically results in similar or somewhat lower emission estimates compared to inversions where this correction is not applied.

The fourth step comprises the conversion of the methane enhancement over the source region, $\triangle X \mathrm{CH}_{4}$, to a source region emission estimate $\left(E_{\mathrm{e}}\right.$; unit: $\mathrm{MtCH}_{4} \mathrm{yr}^{-1}=\mathrm{TgCH}_{4} \mathrm{yr}^{-1}$ ) using conversion factor (CF):

$E_{\mathrm{e}}=\Delta \mathrm{XCH}_{4} \times \mathrm{CF}$.

This assumes that a relatively well-isolated emission source (or region of emission sources) will result in an $\mathrm{XCH}_{4}$ enhancement, $\triangle X \mathrm{XH}_{4}$, in an area at and around the emission hotspot relative to its surrounding, i.e. that there will be a spatial correlation between a local emission and a local $\mathrm{XCH}_{4}$ enhancement (compare also the two maps shown in Fig. 4a and $b$, which will be discussed in detail below).

The CF in Eq. (1) is computed as follows (see also below when discussing Fig. 3, which illustrates our method):

$\mathrm{CF}=M \times M_{\exp } \times L \times V \times C$.

Here $M$ is a constant conversion factor $\left(5.345 \times 10^{-9} \mathrm{MtCH}_{4} \mathrm{~km}^{-12} \mathrm{ppb}^{-1}\right)$ needed to convert a methane mole fraction change to a methane mass change per area for standard conditions, i.e. for surface pressure $p_{\text {surf }}=1013 \mathrm{hPa} . M_{\exp }$ is a dimensionless factor used to correct for the actual mass (mass $M_{i}$ of the $i$ th grid cell). It is calculated using the surface elevation map also used for the determination of the EC as described above:

$M_{\exp }=\frac{<M_{i}>}{M} \approx \frac{<p_{i}>}{1013.0} \approx<e^{-z_{i} / H}>_{i}$.

Here $p_{i}$ is the surface pressure of the $i$ th grid cell (in hPa) and $z_{i}$ is the surface elevation of the $i$ th grid cell (in $\mathrm{km}$ ), $H$ is the assumed scale height $(8.5 \mathrm{~km})$, and $<>$ and $<>_{i}$ denote averaging over all grid cells of the source region. As shown in the following, the uncertainty of our method is not dominated by the approximation used to compute $M_{\exp }$ (namely the use of surface pressure or elevation rather than actual mass).

The dimension of the remaining factor $(L \times V \times C)$ is $\mathrm{km}^{2} \mathrm{yr}^{-1}$, i.e. the area divided by time or length times velocity and can be interpreted as the effective methane emission accumulation time of air parcels travelling over the source region area or the effective velocity $V$ of air parcels travelling an effective length $L$ over the source region. In this study $L$ is length (in $\mathrm{km}$ ) and $V$ is velocity (in $\mathrm{km} \mathrm{yr}^{-1}$ ). We compute $L$ as the square root of the (pre-defined) source area.

Factor $C$ is dimensionless and in this study we use $C=2.0$. This choice is motivated using the simple model of an air parcel travelling with constant horizontal wind speed $V$ over a homogeneous source region of length $L$ accumulating methane during an accumulation time $\tau=L / V$. When leaving the source area, the methane enhancement of the air parcel, i.e. the concentration difference after and before entering the source region, is twice the mean methane enhancement over the source region due to the assumed linear increase of the methane enhancement of the air parcel when travelling over the source region. Our method basically assumes that the emission of the source region only results in a $\mathrm{XCH}_{4}$ enhancement over the source region.

Figure 3 illustrates the methane emission estimation method. It is illustrated how the observed methane enhancement over the source region (region A in Fig. 3a), $\triangle X \mathrm{XH}_{4}$, is related to the source region emission $(\mathrm{E}$, in mass per time), wind speed magnitude $V$, and length of the source region. The source region shown here is a rectangle of area 
(a) Methane SCIAMACHY/ENVISAT IMAP

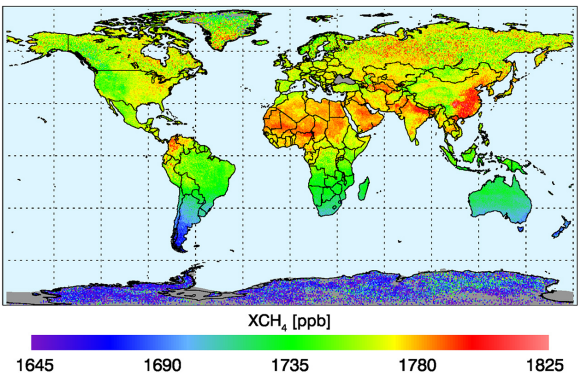

(b) Methane TANSO-FTS/GOSAT OCPR

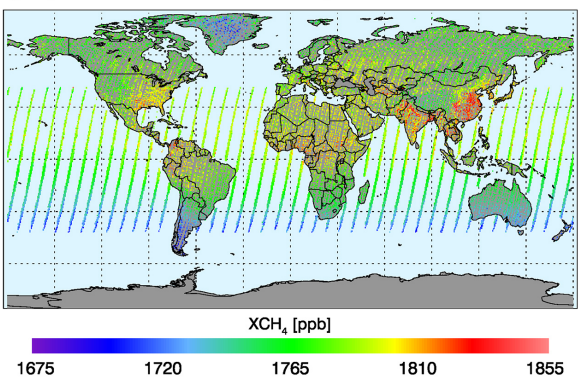

(c) Methane TANSO-FTS/GOSAT SRFP

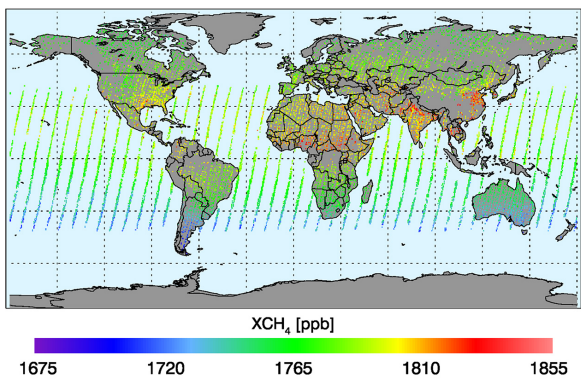

Figure 2. As Fig. 1 but for (a) SCIAMACHY IMAP $\mathrm{XCH}_{4}$, (b) year 2010 GOSAT OCPR $X_{C_{4}}$, and (c) year 2010 GOSAT SRFP ("RemoTeC") $\mathrm{XCH}_{4}$

$A=L_{x} L_{y}$, where wind speed is in the $x$ direction. Length $L$ as given in Eq. (2) corresponds to length $L_{y}$ of Fig. 3.

The computation of the methane mole fraction enhancement over the source region relative to its surrounding, $\triangle X \mathrm{CH}_{4}$, is computed (see also Sect. 4) by subtracting the mean value of $X_{\mathrm{CH}_{4}}$ in the surrounding region (region $\mathrm{B}$ in Fig. 3a) by the mean value of $X_{\mathrm{CH}_{4}}$ over the source region (region A in Fig. 3a). It is assumed that the surrounding region does not contain any (significant) emission sources and that atmospheric methane enhancements in the surrounding area due to outflow from the source region into the surrounding region (region $\mathrm{C}$ in Fig. 3b) can be neglected (the resulting error is small if region $\mathrm{B}$ is much larger than region $\mathrm{C}$ ). As a consequence, the computed mean value of $\mathrm{XCH}_{4}$ in the surrounding is typically overestimated and, therefore, $\triangle X \mathrm{CH}_{4}$ and the computed methane emission are too low; i.e. the estimated emission is typically underestimated.
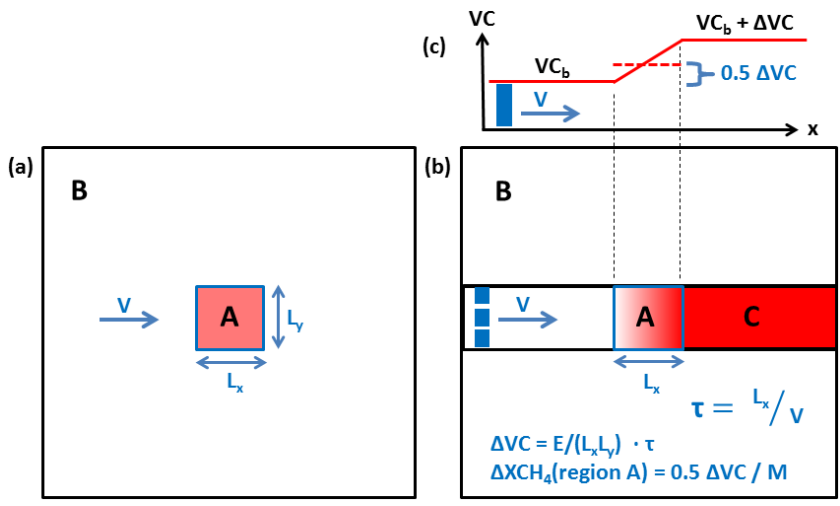

Figure 3. Sketch of a simple model used to explain the methane emission estimation method. (a) Source region A (of size $L_{x} L_{y}$ and with $L_{x}$ in wind direction; wind speed magnitude $V$ ) with elevated $\mathrm{XCH}_{4}$ (light red) and surrounding (background) region $\mathrm{B}$ (white area). (b) Air parcels (blue squares) moving with constant speed $V$ over a source region with emission $E /\left(L_{x} \mathrm{~L}_{y}\right)$, where $E$ is the source area emission in $\mathrm{CH}_{4}$ mass per time, while accumulating methane during accumulation time $\tau\left(=L_{x} / V\right)$. (c) Before entering the source region, the air parcels are characterized by a background methane vertical column, $V C_{\mathrm{b}}$, in units of $\mathrm{CH}_{4}$ mass per area. When leaving the source area their vertical column has been enhanced by $\Delta V C=E /\left(L_{x} L_{y}\right) \times \tau$. When passing over the source region, their vertical column increases linearly and, therefore, the average column enhancement over the source region is $0.5 \times \Delta V C . V C\left(\mathrm{CH}_{4}\right.$ mass per area) can be converted to $\mathrm{XCH}_{4}$ (ppb) via a factor $M$ (unit: mass per area and per ppb).

The method described here and used in Sect. 4 is only applied to time averages of atmospheric $\mathrm{XCH}_{4}$ to obtain time-averaged emissions. This typically means that meteorological situations vary significantly during the selected time period (including large wind speed and wind direction variations) so that detailed structures of the atmospheric methane emission "plumes" originating from local emission sources largely average out, resulting in enhanced atmospheric methane over the source region. It needs to be pointed out that Fig. 3b only illustrates a "snapshot" in time but not the average over a range of wind speeds and wind directions (assumed to be reasonably well approximated by the localized enhancement shown in Fig. 3a). $\triangle X \mathrm{CH}_{4}$ also depends on the (size and shape) of the surrounding region. As explained below, we aim at quantifying the impact of the choice of the surrounding region by varying its size and shape.

Our method (Eqs. 1 and 2) assumes a homogeneous distribution of emission sources ("flat source") within the chosen source region (Fig. 3). However, one would expect that due to atmospheric transport (advection and mixing) the observed atmospheric methane (e.g. for annual averages) typically covers a larger area than the underlying emission region(s). As can be concluded from Eqs. (1) and (2) our method results in an underestimation of the emissions, when this assumption is not valid. This can be seen as follows: let 
(a) Methane CAMS v10-S1NOAA - 2003

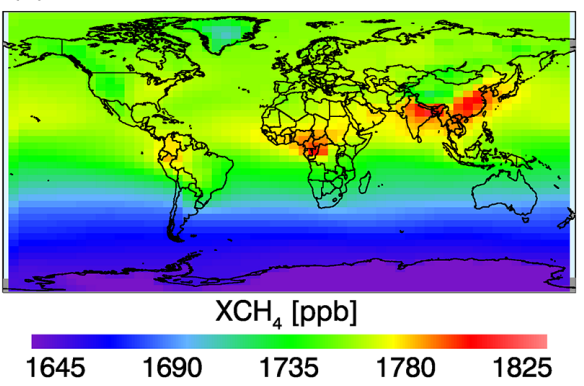

(c) Emission: estimated $\left(E_{e}\right)$ vs.true $\left(E_{t}\right)$

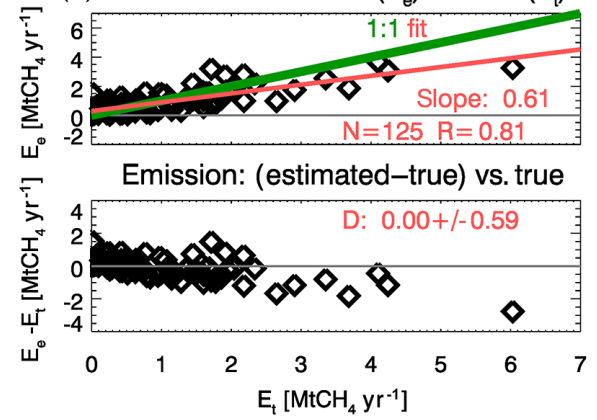

(b) Methane emission v10-S1NOAA

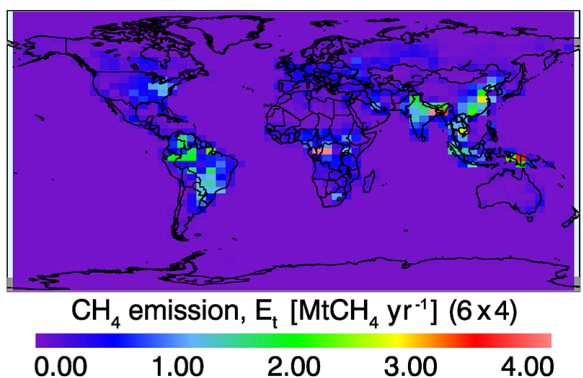

(d) Methane emission estimate

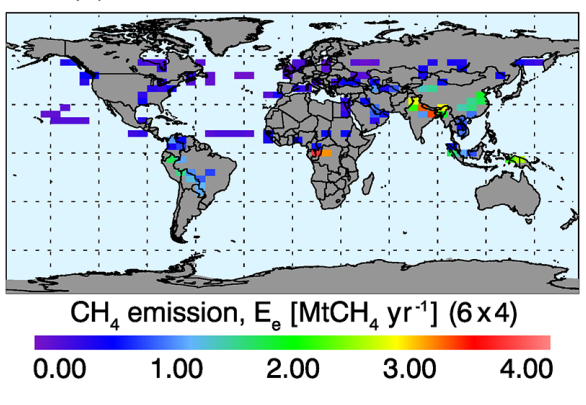

Figure 4. Methane emissions (in $\mathrm{MtCH}_{4} \mathrm{yr}^{-1}$ ) and corresponding $\mathrm{XCH}_{4}$ (in ppb) for the year 2003 at $6^{\circ}$ longitude times $4^{\circ}$ latitude resolution. (a) $\mathrm{XCH}_{4}$ as computed from Copernicus Atmosphere Monitoring Service (CAMS) atmospheric $\mathrm{CH}_{4}$ fields (version v10-S1NOAA; resolution: $6^{\circ} \times 4^{\circ}$; obtained from https://atmosphere.copernicus.eu/). (b) Corresponding CAMS total, i.e. anthropogenic and natural, methane emissions. (d) Methane emissions of (automatically determined potential) emission hotspots ("hotspot cells") as derived from the top left $\mathrm{XCH}_{4}$ map using the method described in Sect. 3. (c) Comparison of retrieved emissions (map bottom right) with the "true" CAMS emissions (map top right). Here $N(=125)$ denotes the number of grid cells for which emission values have been obtained ("hotspot cells"; see main text for details), $R(=0.81)$ is the linear correlation coefficient of retrieved and true emissions, and $D$ is the difference between the retrieved and the true emissions in terms of mean difference and standard deviation $\left(0.00 \pm 0.59 \mathrm{MtCH}_{4} \mathrm{yr}^{-1}\right)$.

us start with a situation in which our assumption is valid; i.e. there is a single homogeneous emission source region and its area is identical with the source region used for our analysis. In this case we obtain a certain value for $\triangle X \mathrm{CH}_{4}$ and convert it to an estimated emission $E_{\mathrm{e}}$ using CF. Now let us assume that the surrounding area does not contain any emission sources. If we now extend the size of the source region (region A in Fig. 3) but do not change the outer boundary of the surrounding region (region B in Fig. 3), the true emission of the extended source region would be the same as before (as no emission sources are added when the source region is extended) but the resulting methane enhancement $\left(\triangle X \mathrm{CH}_{4}\right)$ will decrease because the atmospheric methane enhancement will typically be smaller the larger the distance from the source is. A smaller $\Delta X \mathrm{CH}_{4}$ will result in a smaller value of the estimated emission, $E_{\mathrm{e}}$ (see Eq. 1). CF increases with increasing source region; i.e. the estimated emission not only depends on $\triangle \mathrm{XCH}_{4}$ but also on the size of the source region via $\mathrm{CF}$. The problem is that the increase of $\mathrm{CF}$ is only proportional to $L$, i.e. to the square root of the source area, whereas the decrease of $\Delta X \mathrm{CH}_{4}$ may be proportional to the source area $\left(=L^{2}\right)$. As a result, one would expect an underestimation of the estimated emission. This underestimation in- creases (gets worse) the more inhomogeneous the true emission sources are distributed within the investigated source region (an illustration is given below when discussing Figs. 9 and 10).

The value of $V$ has been obtained by "calibrating" our method using global methane data sets obtained from the Copernicus Atmosphere Monitoring Service (CAMS; https: //atmosphere.copernicus.eu/). Specifically, we use CAMS a posteriori methane emissions and corresponding atmospheric methane version v10-S1NOAA as generated via the TM54DVAR assimilation system assimilating National Oceanic and Atmospheric Administration (NOAA) $\mathrm{CH}_{4}$ surface observations (an earlier version of this method and resulting data products is described in Bergamaschi et al., 2009). The CAMS data set used is based on forward modelling for the computation of atmospheric methane based on prescribed (but optimized) emissions. This is important as the calibration of our method requires atmospheric methane consistent with the underlying methane emissions. Based on this data set we computed annual emissions and corresponding annual $\mathrm{XCH}_{4}$ at the original CAMS data set resolution of $6^{\circ}$ longitude by $4^{\circ}$ latitude. The corresponding maps for the year 2003 are shown in Fig. 4 (top row). 
The CAMS $\mathrm{XCH}_{4}$ map of 2003 shown in Fig. 4a has been used to derive methane emissions using Eq. (1) and varying parameter $V$ (the only free parameter of our model) until the mean difference between our estimated emissions and the "true" CAMS emissions is zero. We found that this is the case for $V=1.1 \mathrm{~m} \mathrm{~s}^{-1}$ (converted to $\mathrm{km} \mathrm{yr}^{-1}$ ). The term "true" as used here (and below) does not imply that the CAMS emissions are perfect, i.e. free of errors. It simply means that these are the emissions which correspond to the atmospheric methane we use to calibrate our method, i.e. the atmospheric concentrations, are computed using these emissions. What matters for our application is that we have a "good enough" modelling of the relationship between emissions and resulting atmospheric concentrations.

The resulting map of retrieved emissions using $V=1.1 \mathrm{~m} \mathrm{~s}^{-1}$ is shown in Fig. 4d. This map has been obtained using an automatic procedure: for all CAMS $6^{\circ} \times 4^{\circ}$ grid cells (except for the ones at the border) the $\mathrm{XCH}_{4}$ value of this grid cell has been obtained and is interpreted as a potential source region value. The neighbouring cells define the surrounding (background) of the potential source region and its $\mathrm{XCH}_{4}$ mean value, and standard deviation has been computed. A methane enhancement, $\triangle X \mathrm{CH}_{4}$, has been computed as "source minus background value" (here "background" refers to the mean $\mathrm{XCH}_{4}$ value in the surrounding region) as described above. If the resulting $\triangle X \mathrm{CH}_{4}$ value is larger than 0.5 times the standard deviation of the $X_{\mathrm{CH}_{4}}$ values in the surrounding, then the corresponding cell is flagged as a methane "hotspot cell" and its $\triangle X \mathrm{XH}_{4}$ value is converted to an emission using the approach described above (Eq. 1). The corresponding results are shown as map in Fig. 4d and can be compared with the "true" emission map shown in Fig. 4b. As can be seen in Fig. 4, $N=125$ hotspot cells have been found using the described procedure.

Figure $4 \mathrm{c}$ shows $x-y$ plots of estimated emissions versus "true" (i.e. CAMS) emissions (top) and estimated minus true emissions versus true emissions (bottom). The mean difference "estimated-true" is $0.00 \mathrm{MtCH}_{4} \mathrm{yr}^{-1}$ (this must be the case as $V=1.1 \mathrm{~m} \mathrm{~s}^{-1}$ has been determined by minimizing this difference). The standard deviation of the difference is $0.59 \mathrm{MtCH}_{4} \mathrm{yr}^{-1}$, the linear correlation coefficient $R$ is 0.81 , and the red line shows the resulting line from a linear fit. As can be seen, the (red) line originating from the linear fit has a positive slope but does not perfectly agree with the (green) $1: 1$ line (our single parameter model does not permit to also optimize the slope of the fitted line).

Figure 5 is similar as Fig. 4 but shows results for the year 2012. Here the difference "estimated-true" is not exactly zero but $0.01 \mathrm{MtCH}_{4} \mathrm{yr}^{-1}$. In contrast to Fig. $4, V$ has not been fitted. Instead, the pre-defined value of $V=1.1 \mathrm{~m} \mathrm{~s}^{-1}$ has been used. Figure 5 shows very similar "estimated-true" differences compared to Fig. 4. This indicates that the effective wind speed V as obtained from year 2003 data is valid also for other years.
The results shown in Figs. 4 and 5 are combined in the single Fig. 6. As can be seen from Fig. 6a, the overall correlation of the retrieved and true emissions is 0.81 , the mean difference (estimated minus true) is $0.00 \mathrm{MtCH}_{4} \mathrm{yr}^{-1}$, and the standard deviation of the difference is $0.53 \mathrm{MtCH}_{4} \mathrm{yr}^{-1}$. As explained, these results have been obtained using constant values for wind speed parameter $V\left(=1.1 \mathrm{~m} \mathrm{~s}^{-1}\right)$ and correction factor $C(=2.0)$ (Eq. 2). Several attempts have been undertaken in order to find out whether the use of regionally and/or time-dependent $V$ or $C$ values can reduce the difference of the estimated and the true methane emission, (so far) without success. For example, it has been investigated whether the emission difference is correlated with mean wind speed (using ECMWF ERA Interim data obtained from www.ecmwf.int/; Dee et al., 2011) but no significant correlation between emission error and spatially resolved annual mean wind has been found. Figure 7 illustrates this using annual mean wind speed at $900 \mathrm{hPa}$. As can be seen, there is essentially no correlation between emission error and mean wind speed $(R=0.049)$. Similar results have been obtained for other pressure levels (e.g. $R=-0.036$ for $800 \mathrm{hPa}$ and $R=0.254$ for the lowest ECMWF ERA Interim model level). This indicates that the use of mean wind speed (from meteorological data) does not help to improve the accuracy of our method. Future studies will show to what extent our method can be improved (or not). The year-to-year variation of the estimated annual emission, $E_{\mathrm{e}}$, for a given satellite $\mathrm{XCH}_{4}$ product is therefore entirely driven by the satellitederived methane enhancement, $\Delta X \mathrm{CH}_{4}$, as parameters $V$ and $C$ are constant.

Finally, the $(1 \sigma)$ uncertainty of $E_{\mathrm{e}}$ has been estimated. This has been done as follows: Fig. 6 also shows the emission difference ("estimated minus true"; see middle and bottom panels) as a function of the estimated emission. Figure 6 middle also shows (in red) the corresponding mean values (crosses) and standard deviations (vertical bars) for several emission bins (non-equidistant to ensure a sufficiently large number of data points within each bin). Also shown in Fig. 6 (b and c) are dotted red lines computed as $\mathrm{f}\left(E_{\mathrm{e}}\right)=0.3+0.5 \times E_{\mathrm{e}}$. This function and its parameters has been chosen such that the red vertical bars ( $1 \sigma$ range) are located within the range defined by $f\left(E_{\mathrm{e}}\right)$; i.e. most of the emission differences are located within $\pm f\left(E_{\mathrm{e}}\right)$ (Fig. 6 middle). Therefore, $f\left(E_{\mathrm{e}}\right)$ is a reasonable description of the $1 \sigma$ uncertainty of the estimated emissions. Based on this it is concluded that the $1 \sigma$ uncertainty of the estimated emission due to uncertainty of the overall CF can be well described using this formula:

$\sigma_{\mathrm{CF}}=0.3+0.5 \times E_{\mathrm{e}}$.

Here the units of $\sigma_{\mathrm{CF}}$ and $E_{\mathrm{e}}$ are $\mathrm{MtCH}_{4} \mathrm{yr}^{-1}$. The total uncertainty, $\sigma_{\text {tot }}$, consists of the uncertainty of the conversion factor, $\sigma_{\mathrm{CF}}$, and the uncertainty of the obtained methane enhancement, $\sigma_{\triangle X \mathrm{CH}_{4}}$, as obtained from the satellite data (see Eq. 1). The latter is assumed to be dominated by methane 
(a) Methane CAMS v10-S1NOAA - 2012

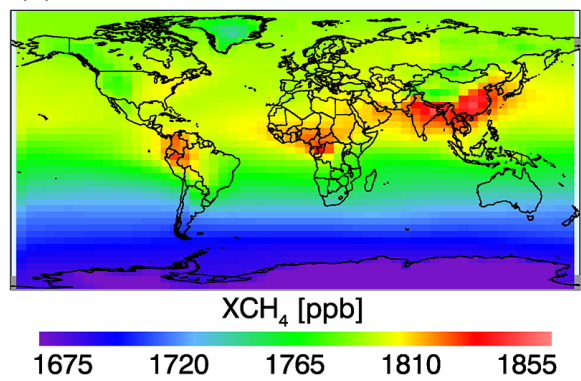

(c) Emission: estimated $\left(E_{e}\right)$ vs.true $\left(E_{t}\right)$

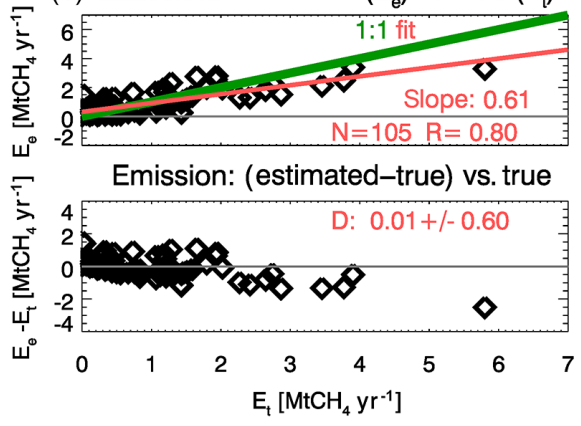

(b) Methane emission v10-S1NOAA

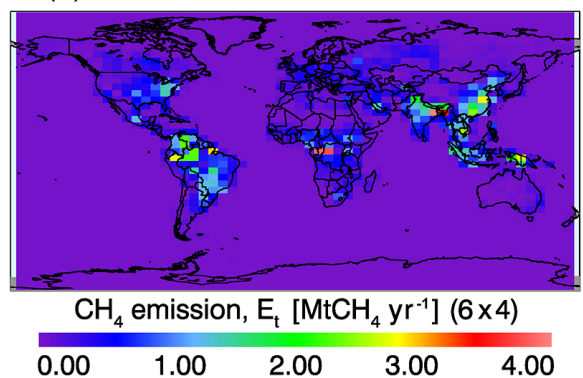

(d) Methane emission estimate

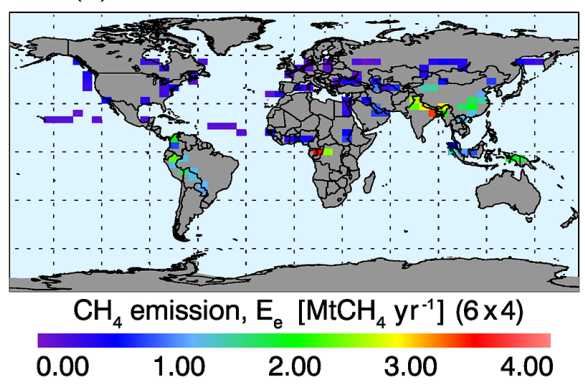

Figure 5. As Fig. 4 but for year 2012.

variations in the surrounding area (primarily because the surrounding region may contain regions of elevated methane due to sources located outside the source region). This contribution to the total uncertainty is estimated by varying the size of the surrounding region (see following section). The total uncertainty is computed as follows:

$\sigma_{\text {tot }}=\sqrt{\sigma_{\Delta X \mathrm{CH}_{4}}^{2}+\sigma_{\mathrm{CF}}^{2}}$.

The method described in this section has been applied to the described SCIAMACHY and GOSAT $\mathrm{XCH}_{4}$ data products and for each of the pre-defined source regions annual average emissions and their uncertainties have been obtained for all products. The results are presented in Sect. 4. Before the method is applied to real data it is relevant to carry out some additional investigations using simulations as in this case the "true emissions" are known. For this purpose, a high-resolution methane data set is used to investigate how well the inversion method performs when using a different model, which simulates atmospheric methane at much higher spatial resolution than the model described and used for the results presented in this section. The high-resolution results are presented in the following Sect. 3.1.

\section{Performance of inversion method as applied to simulations of high-resolution methane}

In order to test the inversion method using a methane data set at higher resolution, simulated atmospheric methane concentrations using posterior methane emissions from Turner et al. (2015) have been used. The spatial resolution of this data set is $0.5^{\circ}$ latitude by $0.667^{\circ}$ longitude and it covers North America. The methane concentrations have been computed with GEOS-Chem. This data set is referred to as GCT15 in this paper. It covers 1 year (2010) and consists of methane emissions and corresponding atmospheric concentrations on the same spatial grid.

Figure 8 shows (around noon) annually averaged GCT15 $\mathrm{XCH}_{4}$ over the USA. As can be seen, there are several regions where methane is significantly enhanced compared to their surrounding areas. However, one would see even more "emission hotspot areas" when magnifying this map and using an appropriate colour scale for the magnified regions.

This is demonstrated in Fig. 9a, which focuses on central California (a region discussed in detail in Sect. 4). As can be seen, there is a region of clearly elevated methane (red colour) located approximately between the two cities of Modesto and Merced (not shown). This region has been selected as a source region shown as polygon (thick black line) in Fig. 9a and is referred to as California(MM) (CMM) in the following. The "surrounding region" as used to compute $\triangle X \mathrm{XH}_{4}$ (via "source - background" $\mathrm{XCH}_{4}$ ) is shown as a white rectangle. As shown in Fig. 9, $\triangle X \mathrm{XH}_{4}$ is $9.4 \mathrm{ppb}$, and the estimated emission of the CMM region, computed using Eq. (1) with the parameters described earlier, is $729 \pm 664 \mathrm{ktCH}_{4} \mathrm{yr}^{-1}$. The GCT15 emissions, i.e. the "true" emissions, are shown in Fig. 9b and the emission is $727 \mathrm{ktCH}_{4} \mathrm{yr}^{-1}$ in the CMM source region. It needs to be pointed out that the GCT15 emissions can be large outside 
(a) Estimated $\left(\mathrm{E}_{\mathrm{e}}\right)$ and true $\left(\mathrm{E}_{\mathrm{t}}\right) \mathrm{CH}_{4}$ emissions

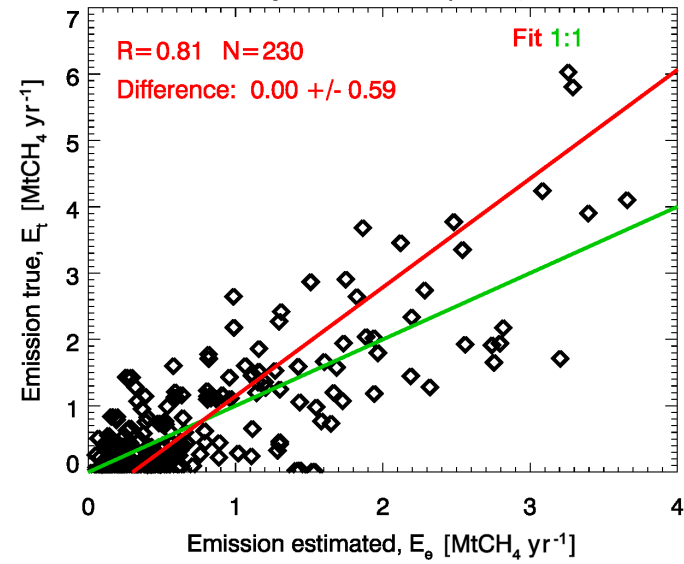

(b)

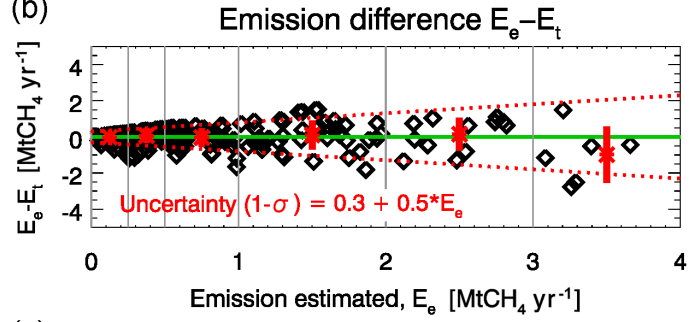

(c)

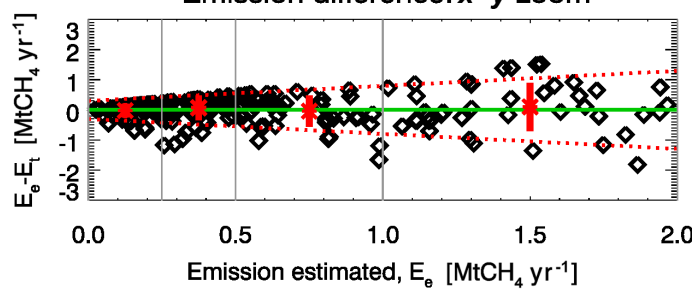

Figure 6. (a) "True" (i.e. CAMS) emission, $E_{t}$, versus estimated emissions, $E_{\mathrm{e}}$, as obtained from the simulation-based assessment results shown in Figs. 4 and 5 (i.e. shown are all "hotspot cells" also shown in these two figures; see caption Fig. 4 and main text for details). (b, c) Emission difference "estimated minus true" versus estimated emission. The grey vertical bars denote the boundaries of emission bins for which mean differences (red crosses) and standard deviations of the differences (red vertical lines) have been computed. The red dotted line shows that the relationship between the estimated emission $\left(E_{\mathrm{e}}\right)$ and its $1 \sigma$ uncertainty $(\sigma)$ can be approximately described by $\sigma\left(E_{\mathrm{e}}\right)=0.3+0.5 E_{\mathrm{e}}$.

the selected CMM source region, in particular in the San Francisco area (the red cell corresponds to an emission of nearly $200 \mathrm{ktCH}_{4} \mathrm{yr}^{-1}$ ) but this major source region is located outside the selected source region, which is defined based (only) on $\mathrm{XCH}_{4}$ (Fig. 9a). The excellent agreement of the estimated emission and the true emission can, of course, be simply by chance in this case. Here it is likely that $\mathrm{XCH}_{4}$ over the CMM region is (due to transport) significantly affected by San Francisco emissions, i.e. by emission located outside the source region (see also Bao et al., 2008, for a discussion of the meteorology in this area). Therefore, one
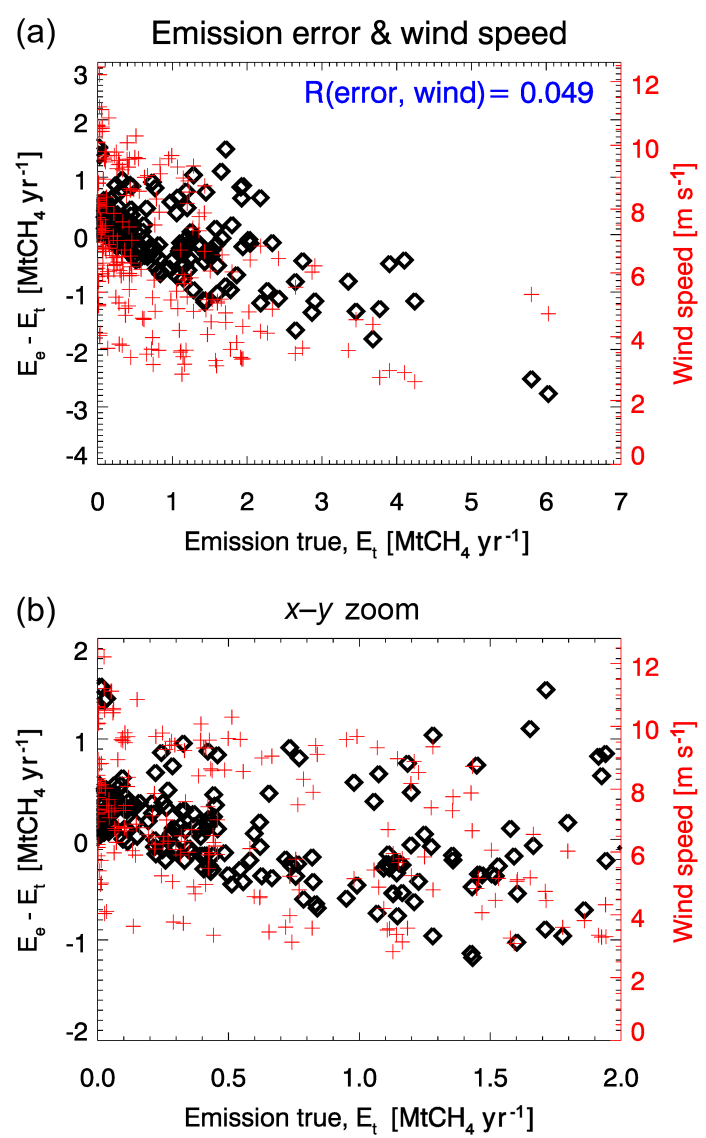

Figure 7. Error of the estimated emission (black symbols; computed as "retrieved-true"; see Fig. 6) versus annual mean wind speed (red crosses) at $900 \mathrm{hPa}$. (a) All data; (b) same data but $x-y$ zoom. The linear correlation coefficient between annual emission error and annual mean wind speed is 0.049 .

has to be careful when interpreting the estimated emissions as they may also be influenced by emission sources in the surroundings. However, there is also outflow from the source region into the surrounding region. All this (and other aspects) results in quite large uncertainty of the estimated emission and this is reflected in the uncertainty estimate, which is quite conservative; i.e. it is quite large. In this case, our estimated $(1 \sigma)$ uncertainty is $664 \mathrm{ktCH}_{4} \mathrm{yr}^{-1}$, which is nearly $100 \%$ of the estimated emission. This uncertainty has been computed for the surrounding region shown in Fig. 9, i.e. by neglecting the additional error contribution due to variations of the surrounding region $\left(\sigma_{\Delta X \mathrm{CH}_{4}}\right.$ in Eq. 1). This contribution is, however, small compared to error term $\sigma_{\mathrm{CF}}$ ( $=664 \mathrm{ktCH}_{4} \mathrm{yr}^{-1}$ in this case). That the total uncertainty is typically clearly dominated by $\sigma_{\mathrm{CF}}$ is a finding that has also been confirmed when analysing the real satellite data (see Sect. 4), where both uncertainty contributions are always considered.

Figure 10 shows similar results to those in Fig. 9 but for an extended source region referred to as California Mid/South, 


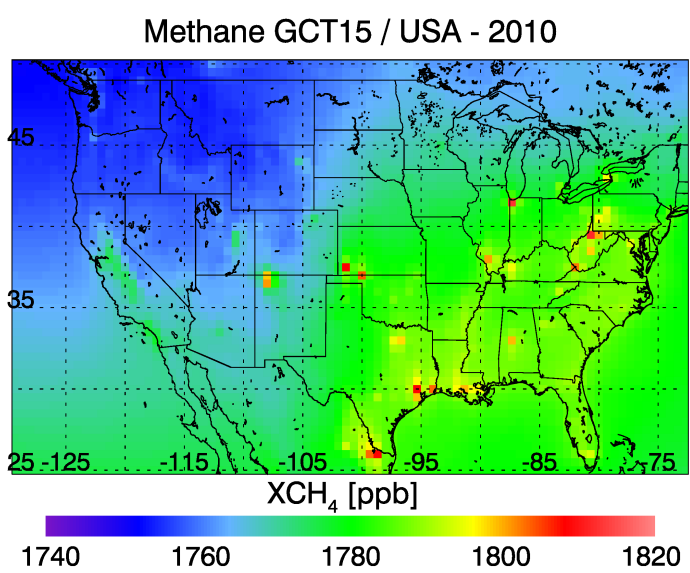

Figure 8. Annually averaged (year 2010) atmospheric columnaveraged methane $\left(\mathrm{XCH}_{4}\right)$ computed with GEOS-Chem using a posteriori methane emissions of Turner et al. (2015) ("GCT15 data set"). The resolution of this data set is $0.5^{\circ}$ latitude $\times 0.667^{\circ}$ longitude.

denoted CMS in the following. This region covers the region from near San Francisco in the north to Los Angeles in the south. As can be seen, $\triangle X \mathrm{CH}_{4}$ is $7.2 \mathrm{ppb}$ and the estimated emission is $770 \pm 685 \mathrm{ktCH}_{4} \mathrm{yr}^{-1}$, which is significantly lower than the "true" CMS region emission of $1228 \mathrm{ktCH}_{4} \mathrm{yr}^{-1}$; i.e. in this case the estimated emission is wrong by $-37 \%$ (computed as "(estimated-true)/true"). However, the true emission is inside the uncertainty range of the $1 \sigma$ range of the estimated emission (but close to the upper edge of the uncertainty range, which is $1455 \mathrm{ktCH}_{4} \mathrm{yr}^{-1}$ ). The reason for this underestimation is very likely due to the fact that the emission sources are distributed very irregularly inside the CMS region. As already explained above, a significant underestimation of the estimated emission is expected in this case.

As can also be seen from Fig. 10a, there is a region of clearly elevated $\mathrm{XCH}_{4}$ in the southern part of the CMS source region. This region corresponds to the Los Angeles area. Figure 11a shows a zoom into this region. In this case we define the source region by a simple rectangle. The estimated Los Angeles area methane emission is $250 \pm 425 \mathrm{ktCH}_{4} \mathrm{yr}^{-1}$, whereas the true emission is $367 \mathrm{ktCH}_{4} \mathrm{yr}^{-1}$, i.e. the difference $-32 \%$ (negative, i.e. the estimated emission is (again) underestimated).

Another interesting source region is the Four Corners, which is discussed in detail in Sect. 4. As shown in Fig. 12, the estimated emission is $795 \pm 697 \mathrm{ktCH}_{4} \mathrm{yr}^{-1}$, whereas the "true emission" is $1404 \mathrm{ktCH}_{4} \mathrm{yr}^{-1}$, i.e. the difference $-43 \%$.

Comparisons of estimated versus true emissions such as those presented here have also been carried out for several other of the methane emission hotspot area shown in Fig. 8. Figure 13 presents an overview of the corresponding results. As can be seen, the estimated emissions are typically un- (a) Methane GCT15 / California(MM) - 2010

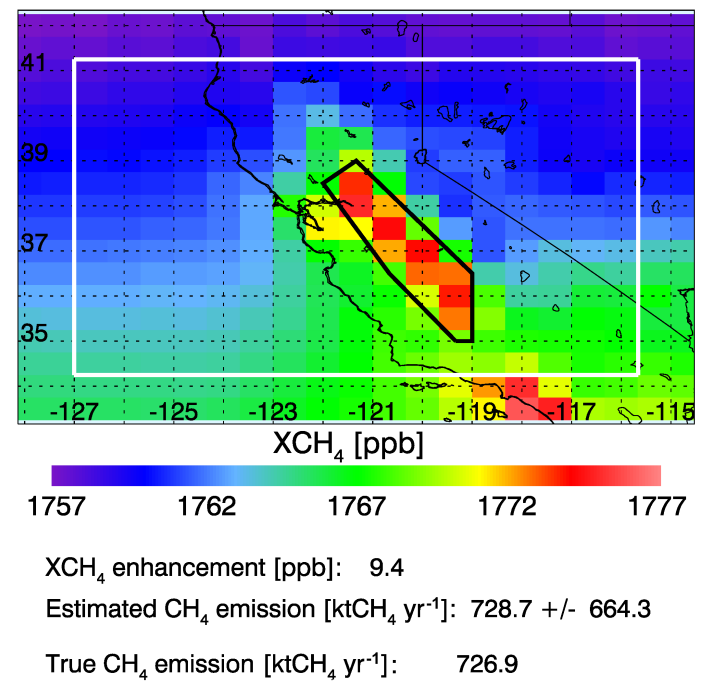

(b) Methane emission GCT15

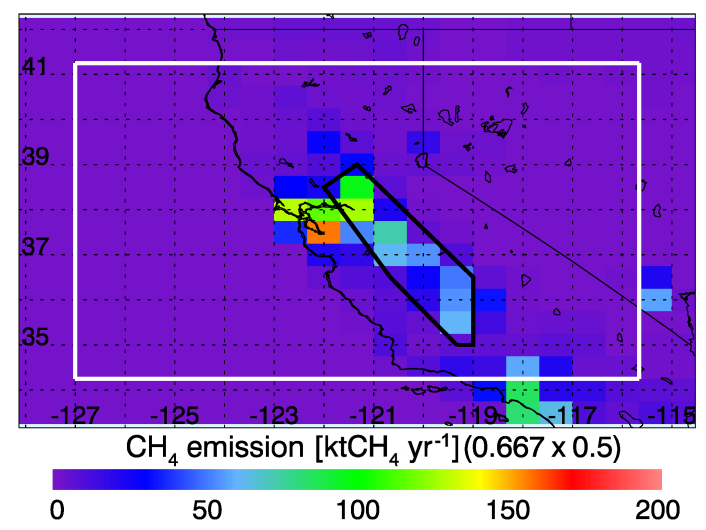

Figure 9. (a) GCT15 $\mathrm{XCH}_{4}$ over parts of California. The white rectangle denotes the "surrounding region" of the "source region", which is surrounded by a polygon shown as thick black line. The source region covers the area between the two cities Modesto and Merced in central California. The text below (a) lists the $X_{\mathrm{CH}_{4}}$ enhancement, $\triangle X \mathrm{CH}_{4}(9.4 \mathrm{ppb})$, and the estimated emission $\left(729 \pm 664 \mathrm{ktCH}_{4} \mathrm{yr}^{-1}\right)$. The "true" emission of the source region has been computed from the GCT15 emissions (bottom panel) and is $727 \mathrm{ktCH}_{4} \mathrm{yr}^{-1}$.

derestimated by about $40 \%$. The emission uncertainties are large (on the order of $100 \%$ ) but the true emissions are within the $1 \sigma$ uncertainty estimate of the estimated emission (the one exception being the Chicago area, where the true emission is $1473 \mathrm{ktCH}_{4} \mathrm{yr}^{-1}$ but the upper $(1 \sigma)$ range of the estimated emission is $1322 \mathrm{ktCH}_{4} \mathrm{yr}^{-1}$ ). Based on these results it is concluded that the estimation method as described in this paper provides reasonable results but with a clear tendency to underestimate the emissions (as expected from the theoretical considerations presented earlier). To what extent the $40 \%$ value depends on the model used (in this case GEOS-Chem) and on its characteristics (such as spatio-temporal resolution) 
(a) Methane GCT15 / California(MS) - 2010

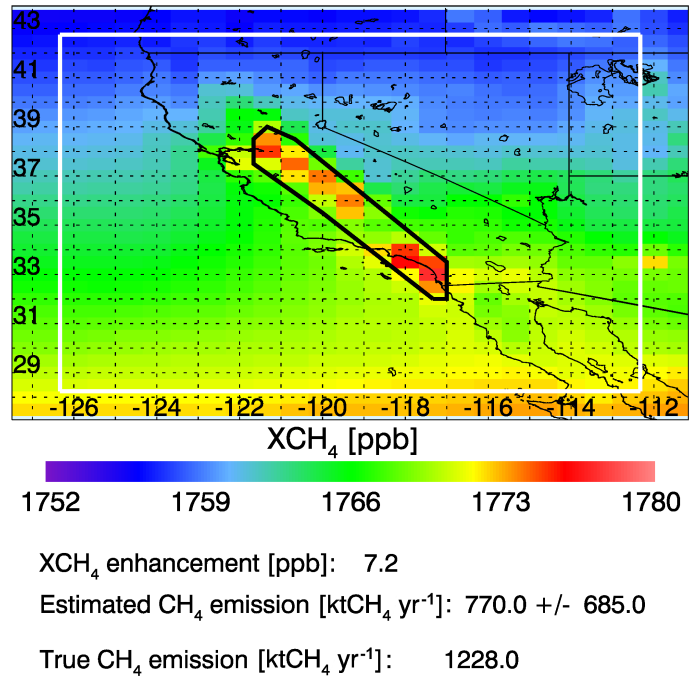

(b) Methane emission GCT15

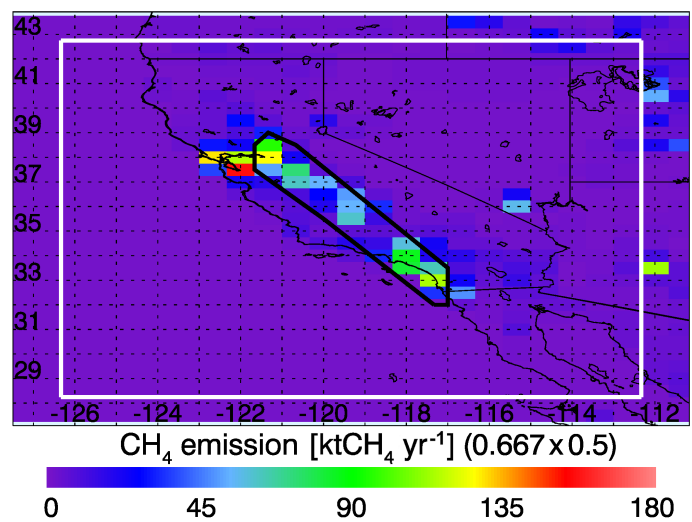

Figure 10. As Fig. 9 but for a larger part of California, referred to as California Mid/South (CMS) in this publication.

needs to be investigated (e.g. by using also other models). In any case, the results presented in this section need to be considered when interpreting results obtained from applying this method to real satellite $\mathrm{XCH}_{4}$ retrievals as presented in the following section.

\section{Results and discussion}

In this section we present the results from applying the methane emission inversion method described in the previous section to obtain emission estimates from satellite $\mathrm{XCH}_{4}$ retrievals for four areas: the Four Corners area in the southwestern USA (Sect. 4.1), the southern part of the Central Valley in California (Sect. 4.2), and the two countries Azerbaijan and Turkmenistan (Sect. 4.3). All these areas show elevated methane relative to their surrounding areas (Fig. 1). The spatial locations of these areas as well as key parameters used to convert the observed methane enhancements to (a) Methane GCT15 / Los Angeles - 2010

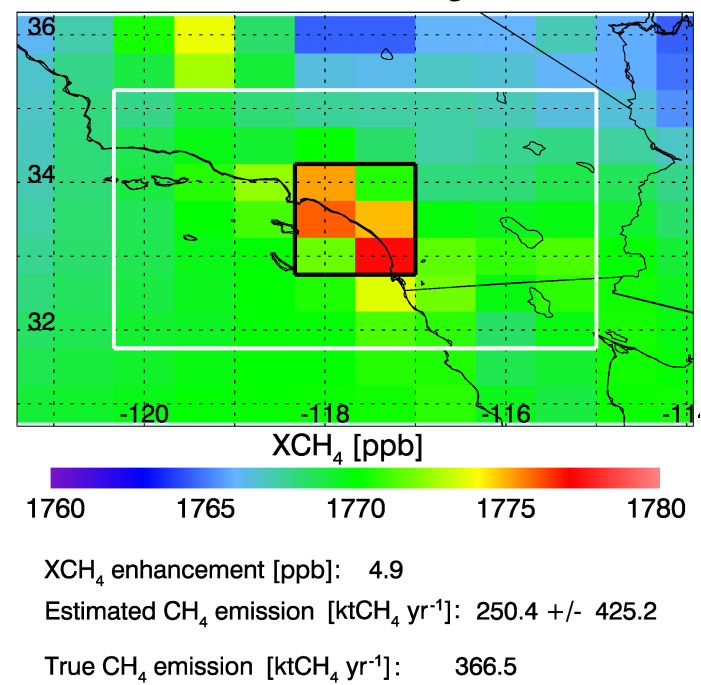

(b) Methane emission GCT15

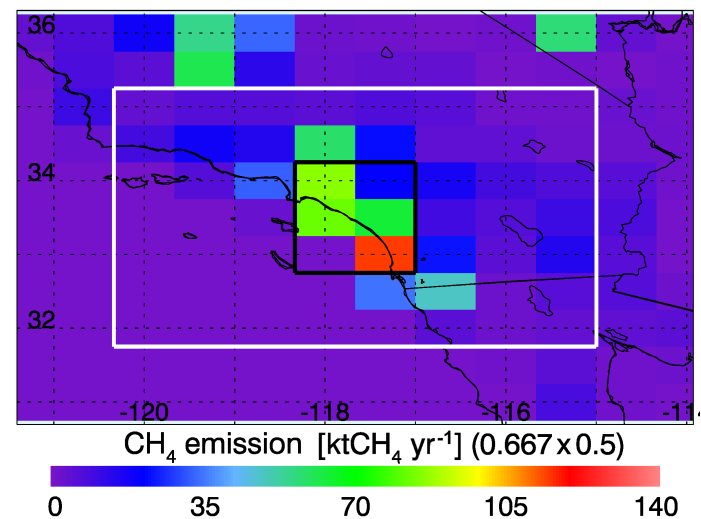

Figure 11. As Fig. 9 but for the region around Los Angeles, California (this region is located in the southern part of the source region shown in Fig. 10).

annual methane emissions are listed in Table 2. The results are summarized in Table 3 and how these results have been obtained is described in the following subsections.

\subsection{Four Corners area, USA}

Four Corners is a region in the USA named after the quadripoint where the boundaries of the four states Utah, Colorado, Arizona, and New Mexico meet. The Four Corners area is one of the largest methane hotspots in the USA (Kort et al., 2014; Wecht et al., 2014b; Frankenberg et al., 2016). The San Juan Basin, located in the Four Corners area, is a geologic structural basin and primarily a natural gas production area, mostly from coal bed methane and shale formations (e.g. Frankenberg et al., 2016, and references given therein). Figure 14 shows annually averaged $\mathrm{XCH}_{4}$ from the four satellite $\mathrm{XCH}_{4}$ products as used in this study at and around Four Corners. Here the $\mathrm{XCH}_{4}$ is shown as an anomaly to be able to 
Table 2. Details related to the four source regions and their parameters as used for the emission estimation.

\begin{tabular}{lrrrrr}
\hline $\begin{array}{l}\text { Source } \\
\text { region }\end{array}$ & $\begin{array}{r}\text { Latitude } \\
\text { range } \\
\left({ }^{\circ}\right)\end{array}$ & $\begin{array}{r}\text { Longitude } \\
\text { range } \\
\left({ }^{\circ}\right)\end{array}$ & $\begin{array}{c}\text { Mexp* } \\
(-)\end{array}$ & $\begin{array}{r}\text { Length L } \\
(\mathrm{km})\end{array}$ & $\begin{array}{r}\text { Overall } \\
\text { conversion } \\
\text { factor* } \\
\left.\mathrm{pb}^{-1}\right)\end{array}$ \\
\hline $\begin{array}{l}\text { Four Corners } \\
\text { Central Valley } \\
\text { (southern part) }\end{array}$ & $36.2-37.4$ & $109.6 \mathrm{~W}-107.0 \mathrm{~W}$ & 0.79 & 176.5 & 0.0518 \\
Azerbaijan & Country shape & 0.94 & 294.3 & 0.0605 \\
Turkmenistan & Country shape & 0.98 & 698.6 & 0.1026 \\
\hline
\end{tabular}

* Approximate values (the exact values depend on the sampling of the satellite data in the source region, which depends on satellite product and year).

(a) Methane GCT15 / FourCorners - 2010

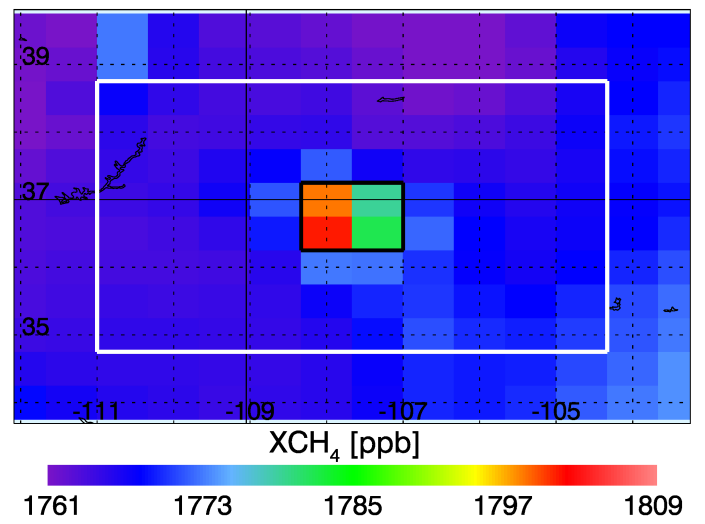

$\mathrm{XCH}_{4}$ enhancement $[\mathrm{ppb}]: 23.8$

Estimated $\mathrm{CH}_{4}$ emission $\left[\mathrm{ktCH}_{4} \mathrm{yr}^{-1}\right.$ ]: $794.8+/-697.4$

True $\mathrm{CH}_{4}$ emission $\left[\mathrm{ktCH}_{4} \mathrm{yr}^{-1}\right]: \quad 1404.2$

(b) Methane emission GCT15

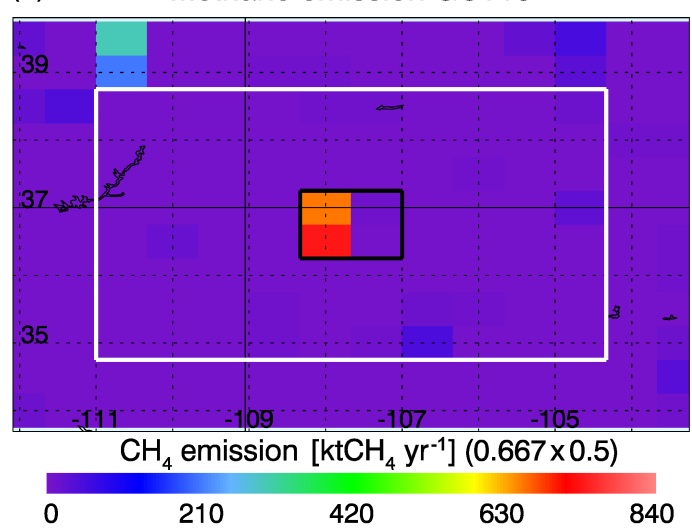

Figure 12. As Fig. 9 but for the Four Corners region (see main text for details).

better compare the spatial pattern of the shown data products. As can be seen, all satellite products show that $\mathrm{XCH}_{4}$ is enhanced in the Four Corners area relative to the surrounding area (for the OCPR product this is difficult to see because the obtained enhancement is the smallest of all products). Figure 14 shows the chosen source region as a (inner) rectangle. The outer rectangle (see figures in last column and last row) shows the "default" surrounding area. As described above, the methane enhancement $\Delta \mathrm{XCH}_{4}$ is computed as the difference between the $\mathrm{XCH}_{4}$ mean value in the source region minus the $\mathrm{XCH}_{4}$ mean value in the surrounding region. For the inversion the size of the surrounding area is varied to determine the sensitivity of the computed $\triangle \mathrm{XCH}_{4}$ with respect to the chosen surrounding region. For this purpose, the latitudes and longitudes of the rectangular box, which defines the surrounding area, are varied by adding all combinations of $0,1,2$, and $3^{\circ}$ in the latitude and longitude directions. The standard deviation of the resulting $\triangle \mathrm{XCH}_{4}$ is used as an estimate of $\sigma_{\triangle X \mathrm{CH}_{4}}$ (see Eq. 1).

Figure 15 shows the resulting $\mathrm{XCH}_{4}$ enhancements for all years and all satellite data products including $(1 \sigma)$ uncertainty estimates (i.e. $\sigma_{\triangle X \mathrm{CH}_{4}}$ ) as vertical bars. As can be seen, all $\triangle X \mathrm{CH}_{4}$ values are positive. This shows that a positive Four Corners methane enhancement is present for all years in all satellite products. The methane enhancement is on average about $10 \mathrm{ppb}$ but shows significant variation depending on satellite product and year.

These methane enhancements and their uncertainties are converted to Four Corners area annual methane emissions using the method described in Sect. 3. The results are shown in Fig. 16. The estimated emissions are in the range 0.42$0.57 \mathrm{MtCH}_{4} \mathrm{yr}^{-1}$ (range of annual mean values of the four satellite products). Taking into account the (large) uncertainty of the estimated annual emissions, this is in good agreement with published values as shown in Fig. 16. For example, Kort et al. (2014) report $0.59 \mathrm{MtCH}_{4} \mathrm{yr}^{-1}$ for the time period 2003-2009 (based on SCIAMACHY and ground-based Fourier transform (FT) spectrometer observations) and Turner et al. (2015) report the range of 0.45-1.39 $\mathrm{MtCH}_{4} \mathrm{yr}^{-1}$ for the time period 2009-2011 (based on an analysis of GOSAT data). The good agreement with the published values indicates that the method used here appears to be capable of delivering reasonable emission estimates even when the source area is much smaller than the $6^{\circ} \times 4^{\circ}$ re- 


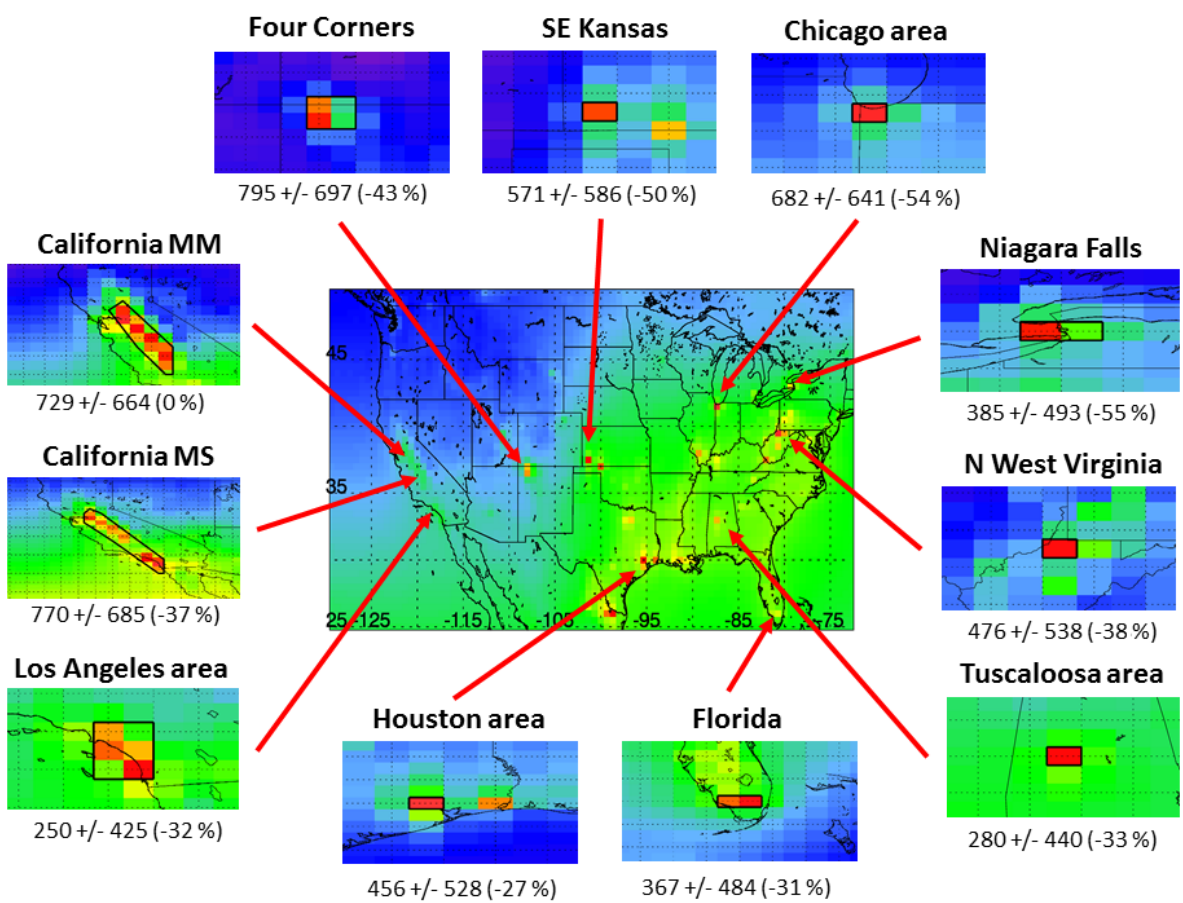

Figure 13. Methane emission estimates for several methane hotspot areas in the USA as obtained by applying out simple mass balance

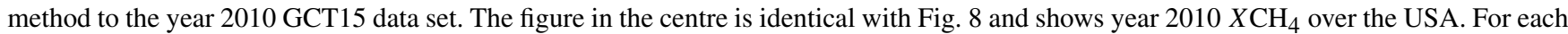
hotspot region the following three numbers are listed below each map: estimated methane and its uncertainty in $\mathrm{ktCH}_{4} \mathrm{yr}^{-1}$ for the shown source regions (thick black lines, mostly rectangles). The number in brackets is the percentage difference of the estimated emission and the corresponding true emission (computed as (estimated-true)/true), where the true emission is the source region GCT15 emission.

Table 3. Summary of estimated methane emissions in terms of annual mean value and $1 \sigma$ range obtained from computing the standard deviation of the annual emissions. The satellite-derived annual methane emissions are covering the time period 2003-2009 for SCIAMACHY and 2009-2014 for GOSAT.

\begin{tabular}{|c|c|c|c|c|c|}
\hline \multirow[b]{3}{*}{ Source region } & \multicolumn{4}{|c|}{ Estimated methane emissions $\left(\mathrm{MtCH}_{4} \mathrm{yr}^{-1}\right)$} & \multirow[b]{3}{*}{$\begin{array}{l}\text { Comments/ } \\
\text { other estimates }\end{array}$} \\
\hline & \multicolumn{2}{|c|}{ SCIAMACHY } & \multicolumn{2}{|c|}{ GOSAT } & \\
\hline & WFMD & IMAP & OCPR & SRFP & \\
\hline Four Corners & $\begin{array}{r}0.50 \\
{[0.40,0.59]}\end{array}$ & $\begin{array}{r}0.57 \\
{[0.34,0.80]}\end{array}$ & $\begin{array}{r}0.45 \\
{[0.14,0.76]}\end{array}$ & $\begin{array}{r}0.42 \\
{[0.20,0.64]}\end{array}$ & $\begin{array}{l}\text { Kort et al. }(2014)^{*}: \\
0.59[0.54,0.64] \\
\text { Turner et al. }(2015) \text { : } \\
{[0.45,1.39]} \\
\text { EDGAR v4.2: } 0.17\end{array}$ \\
\hline $\begin{array}{l}\text { Central Valley } \\
\text { (southern part) }\end{array}$ & $\begin{array}{r}1.05 \\
{[0.53,1.57]}\end{array}$ & $\begin{array}{r}1.10 \\
{[0.92,1.28]}\end{array}$ & $\begin{array}{r}1.35 \\
{[0.96,1.75]}\end{array}$ & $\begin{array}{r}1.55 \\
{[1.15,1.95]}\end{array}$ & $\begin{array}{l}\text { EDGAR v4.2: } 0.19 \\
\text { Jeong et al. (2013): } \\
0.85-0.94 \\
\text { (for their region R12) }\end{array}$ \\
\hline Azerbaijan & $\begin{array}{r}0.60 \\
{[-0.01,1.21]}\end{array}$ & $\begin{array}{r}0.53 \\
{[0.23,0.83]}\end{array}$ & $\begin{array}{r}0.51 \\
{[-0.16,1.18]}\end{array}$ & - & $\begin{array}{l}\text { EDGAR v4.2 } \\
\text { (FT2012): } 0.74\end{array}$ \\
\hline Turkmenistan & $\begin{array}{r}1.89 \\
{[1.22,2.55]}\end{array}$ & $\begin{array}{r}1.93 \\
{[1.66,2.19]}\end{array}$ & $\begin{array}{r}2.08 \\
{[1.67,2.49]}\end{array}$ & $\begin{array}{r}1.85 \\
{[1.31,2.39]}\end{array}$ & $\begin{array}{l}\text { EDGAR v4.2 } \\
\text { (FT2012): } 1.33\end{array}$ \\
\hline
\end{tabular}

\footnotetext{
* Kort et al. (2014), report the $2 \sigma$ range [0.50, 0.67], not the (approximate) $1 \sigma$ range listed here.
} 

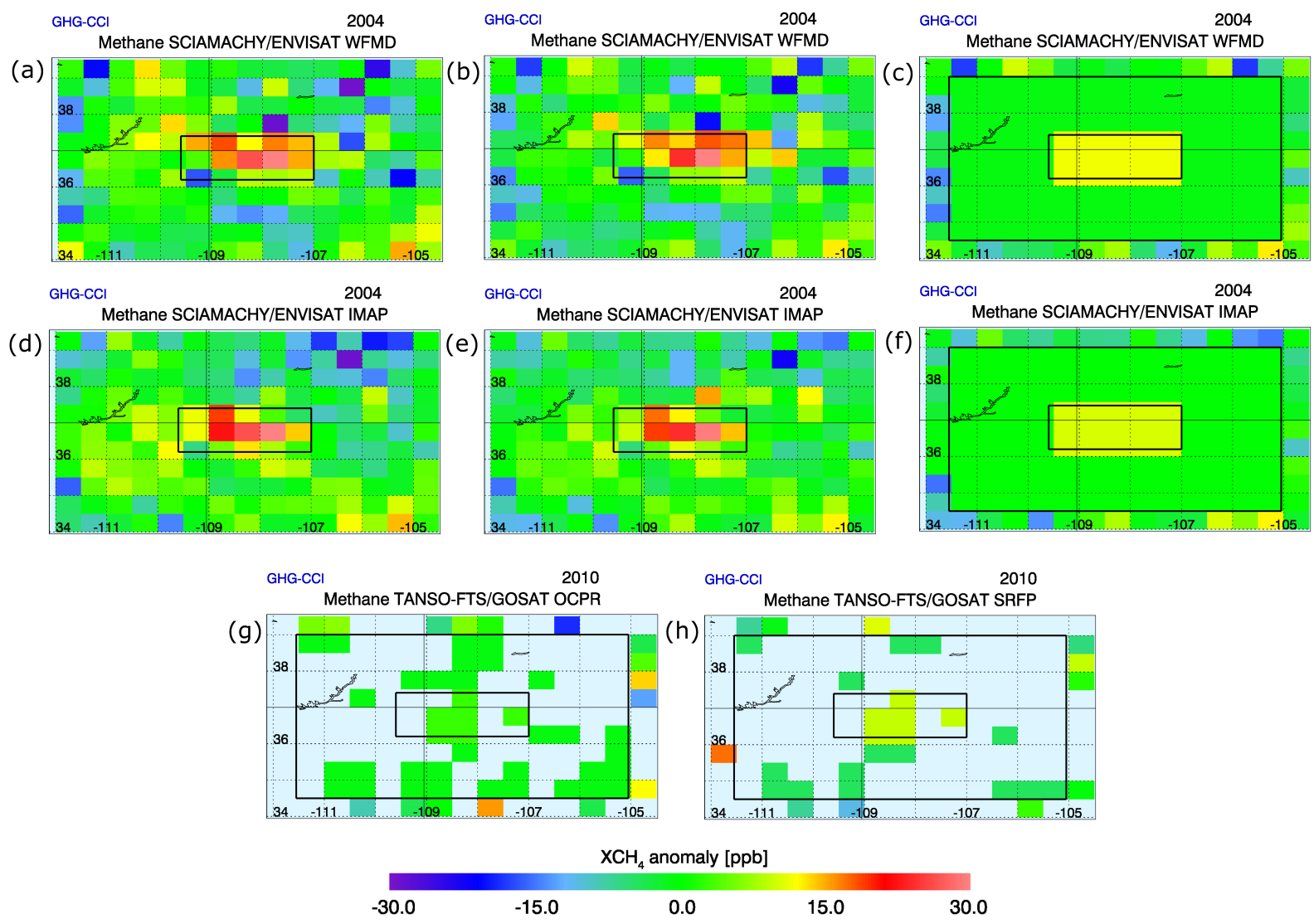

Figure 14. Satellite-derived $\mathrm{XCH}_{4}$ anomalies (i.e. the mean value of $\mathrm{XCH}_{4}$ has been subtracted) in and around the Four Corners region. (a, b, c) SCIAMACHY WFMD year $2004 \mathrm{XCH}_{4}$ anomaly at $0.5^{\circ} \times 0.5^{\circ}$ resolution. (a) Originally gridded data. The black rectangle indicates the assumed source area (taken from Kort et al., 2014). (b) As (a) but after elevation correction (see main text for details). (c) As (b) but replacing the individual $\mathrm{XCH}_{4}$ values by their averages in the indicated source region (inner rectangle) and its surrounding (outer rectangle). The difference between these two values defines the methane enhancement of the source region, i.e. $\Delta X \mathrm{CH}_{4}$. $(\mathbf{d}$, e, $\mathbf{f})$ As top row but for IMAP $X \mathrm{CH}_{4} \cdot(\mathbf{g}, \mathbf{h})$ As last column of first two rows but for GOSAT OCPR $(g)$ and SRFP $(h)$ for the year 2010.

gions used for calibrating our inversion method. The agreement is surprisingly good given the large $(1 \sigma)$ uncertainty values shown in Fig. 16 (approx. 0.6 $\mathrm{MtCH}_{4} \mathrm{yr}^{-1}(\sim 100 \%)$ and dominated by $\sigma_{\mathrm{CF}}$ as can be concluded from a comparison with $\sigma_{\triangle X \mathrm{CH}_{4}}$ shown in Fig. $\left.16(\sim 20 \%)\right)$. Our reported uncertainty of the annual averages seems to be too conservative (at least for quantifying the Four Corners area emissions).

Figure 16 also shows the total anthropogenic emissions during 2003-2008 as obtained from the EDGAR v4.2 database (obtained from http://edgar.jrc.ec.europa.eu/gallery. php?release $=\mathrm{v} 42 \&$ substance $=\mathrm{CH} 4 \&$ sector $=$ TOTALS) for the Four Corners source region. The mean value of the annual EDGAR emissions is $0.17 \mathrm{MtCH}_{4} \mathrm{yr}^{-1}$. As can be seen, the EDGAR emissions are too low by approximately a factor of 3 .

\subsection{Central Valley, California, USA}

California emits large amounts of methane, approximately 2-3 $\mathrm{MtCH}_{4} \mathrm{yr}^{-1}$ (Turner et al., 2015) and major emission sources are livestock, gas/oil, and landfills/wastewater (e.g. Wecht et al., 2014b). According to the EDGAR v4.2 emission database, total anthropogenic methane emissions are largest around Los Angeles and San Francisco, dominated by landfill/wastewater- and gas/oil-related emissions, and in the area in between, in the Central Valley, emissions are dominated by livestock emissions (see Wecht et al., 2014b, their Fig. 1).

The Central Valley in California shows up as a methane hotspot in satellite data (see Fig. 17), with the largest values in the southern part of the Central Valley around Bakersfield, an important oil- and gas-producing area (e.g. Jeong et al., 2014; Guha et al., 2015) and an area with significant methane emissions from dairy and livestock (e.g, Wecht et al., 2014b; Guha et al., 2015), extending up to the city of Fresno or even further towards Modesto/San Francisco. This 


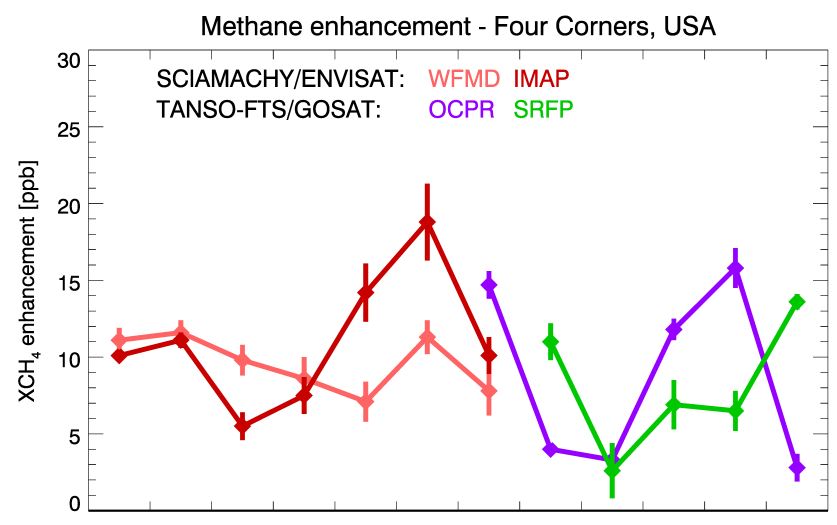

2003200420052006200720082009201020112012201320142015 Time [year]

Figure 15. Methane enhancements over the Four Corners area for all years and all four satellite data products used in this study. The error bars show the standard deviation of the methane enhancements obtained by varying the size and shape of the surrounding area.

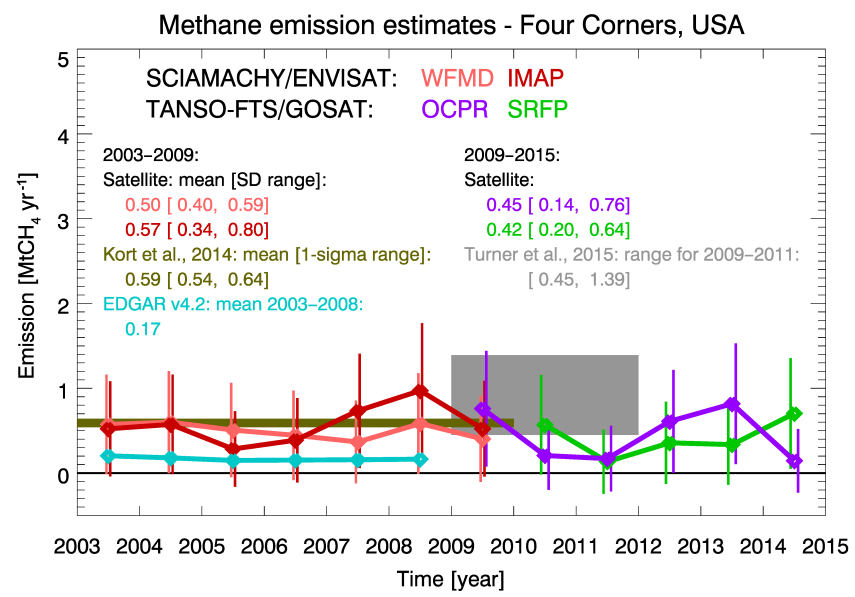

Figure 16. Methane emission estimates for Four Corners as obtained from the methane enhancements shown in Fig. 15. Shown here are the satellite-derived annual methane emissions and their $1 \sigma$ uncertainty as derived from the four satellite data products used in this study using the method described in Sect. 3. The listed numerical values for the satellite-derived emissions are the mean value and a range defined as mean value plus/minus 1 times the standard deviation of the annual averages. The results are compared with published values as listed in Kort et al. (2014) (for 2003-2009; shown in dark green) and Turner et al. (2015) (for 2009-2011; shown in grey). Also shown are the EDGAR v4.2 total anthropogenic emissions during 2003-2008 (in light blue). It needs to be pointed out that the estimated emissions using satellite data are total methane emissions, whereas EDGAR is (only) anthropogenic.

southern part of the Central Valley is the San Joaquin Valley. In this study we define Central Valley as the rectangular region specified by the latitude-longitude range as listed in Table 2, corresponding to the region where the satellite $\mathrm{XCH}_{4}$ is highest. This region roughly corresponds to the San Joaquin
Valley. According to EDGAR this region is dominated by livestock methane emissions with significant contributions from gas/oil- and landfill/wastewater-related emissions (see also Maasakkers et al., 2016, for a recent US methane emission inventory and comparison with EDGAR v4.2).

Figure 17 shows SCIAMACHY WFMD (and IMAP) $\mathrm{XCH}_{4}$ for year 2004 over California and also shows the Central Valley source region as defined for this study (inner rectangle of Fig. 17a) and its "default" surrounding area (outer rectangle Fig. 17b). Figure 17 also shows EDGAR v4.2 total anthropogenic methane emissions for the year 2004 regridded to $0.5^{\circ} \times 0.5^{\circ}$. As can be seen, the spatial pattern of the EDGAR emissions significantly deviates from the spatial pattern of the satellite $\mathrm{XCH}_{4}$. Whereas in EDGAR the highest values are around San Francisco and around Los Angeles, the satellite-derived atmospheric methane is highest in the area in between, in the Central Valley, particularly in the area around Bakersfield. Methane emissions in the Bakersfield region are supposed to be dominated by dairy and livestock operations (Guha et al., 2015, and references given therein).

For comparison with the satellite data and the EDGAR emissions also the CAMS emissions are shown (Fig. 17 bottom row). On the left (Fig. 17e) the CAMS v10-S1NOAA product is shown, which is based on the assimilation of NOAA methane observations, and on the right is the product v10-S1SCIA (Fig. 17f) based on the additional assimilation of SCIAMACHY IMAP $\mathrm{XCH}_{4}$. Surprisingly, the assimilation of SCIAMACHY $X_{\mathrm{CH}_{4}}$ reduces the derived methane emissions in this region. That the Central Valley SCIAMACHY $\mathrm{XCH}_{4}$ enhancement is not modelled well with optimized emissions obtained from assimilating SCIAMACHY data using the global TM5-4DVAR system is also clearly visible in Bergamaschi et al. (2009) (their Fig. 2), discussing an earlier (pre-CAMS) version of this data set. As already mentioned, the emissions of California are expected to be in the range 2-3 $\mathrm{MtCH}_{4} \mathrm{yr}^{-1}$ (see Turner et al., 2015, their Fig. 6), i.e. larger than the v10-S1NOAA (Fig. 17e) and v10-S1SCIA (Fig. 17f) products suggest. The exact reason why the assimilation of the SCIAMACHY data does not lead to larger estimated emissions in this region is unclear but very likely this is due to the fact that the CAMS inversion system is a global system at quite low spatial resolution and therefore not necessarily optimal for proving reliable emission estimates for regions which are smaller or just on the order of the size of the $6^{\circ} \times 4^{\circ}$ grid cells shown in Fig. 17 (bottom rows).

As can be seen from Fig. 18, we obtain mean annual emissions in the range of $1.05-1.55 \mathrm{MtCH}_{4} \mathrm{yr}^{-1}$, depending on the data product. The estimated uncertainty of the annual emissions is $\sim 1 \mathrm{MtCH}_{4} \mathrm{yr}^{-1}(1 \sigma)$ and the interannual variations are $20-50 \%(1 \sigma)$ of the mean emissions, depending on product. Our annual emission estimates are quite uncertain with mean values much higher compared to the emissions as given in the EDGAR v4.2 anthropogenic methane emission inventory. According to EDGAR the total anthropogenic methane emissions in the selected source area are around 

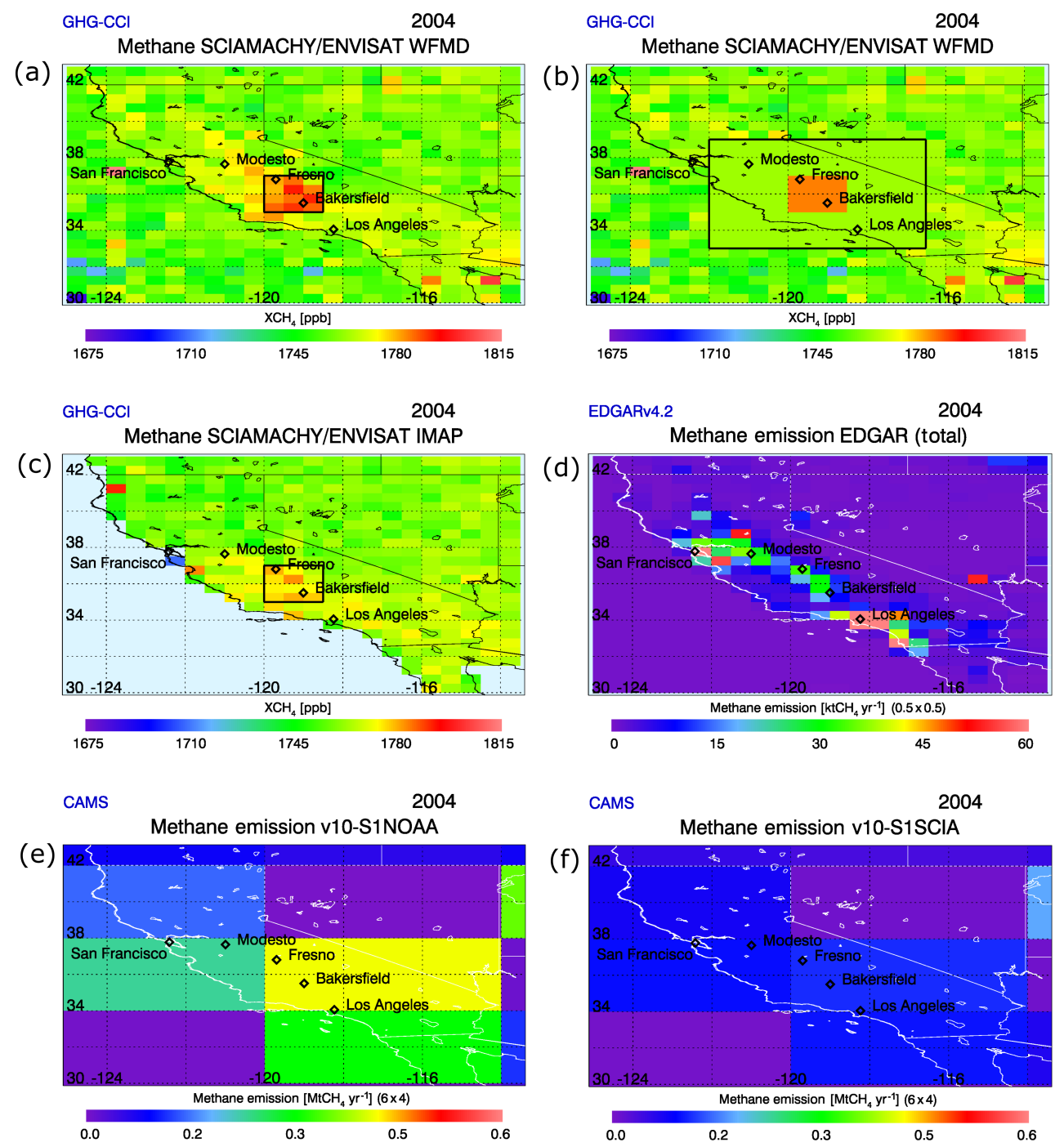

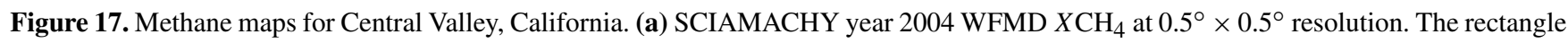
shows the chosen source region. (b) As (a) but showing the source region (inner rectangle) and the default background region (outer rectangle) with their corresponding $\mathrm{XCH}_{4}$ mean values. (c) As (a) but for IMAP. (d) EDGAR v4.2 year 2004 total anthropogenic methane emissions (regridded to $0.5^{\circ} \times 0.5^{\circ}$ resolution). (e) CAMS v10-S1NOAA year 2004 total methane, i.e. anthropogenic and natural, emissions obtained by assimilation of NOAA methane observations (at $6^{\circ} \times 4^{\circ}$ ). (f) As (e) but for CAMS version v10-S1SCIA, i.e. including the assimilation of SCIAMACHY IMAP retrievals in addition to the assimilation of NOAA data.

$0.19 \mathrm{MtCH}_{4} \mathrm{yr}^{-1}$, i.e. a factor of 5-8 lower than our annual mean estimates. This is unlikely due to the fact that our emissions are total emissions whereas EDGAR only reports anthropogenic emissions as the fraction of natural methane emissions in California is estimated to be only approximately $3 \%$ percent (Wecht et al., 2014b). Our results are broadly consistent with recently published results from CalNex campaign (May-June 2010) aircraft observations (Wecht et al., 2014b) that also show high-atmospheric methane concentrations over the southern Central Valley compared to the rest of California and conclude that EDGAR emissions in this region need to be scaled with factors up to around 5 (see their Fig. 2). Wecht et al. (2014a) also derived emissions in this area using SCIAMACHY IMAP retrievals. They report that their derived emissions are consistent with the ones presented in Wecht et al. (2014b), and for the Central Valley they found that the derived emissions are a factor of 2-4 higher compared to EDGAR v4.2 (their definition of Central Valley is not exactly identical with our definition, which is restricted to the southern part of the Central Valley). They conclude that the livestock emissions in EDGAR are significantly underestimated.

Jeong et al. (2013) present an analysis of methane emissions using atmospheric observations from five sites in California's Central Valley across different seasons (September 2010 to June 2011). They obtained spatially resolved 


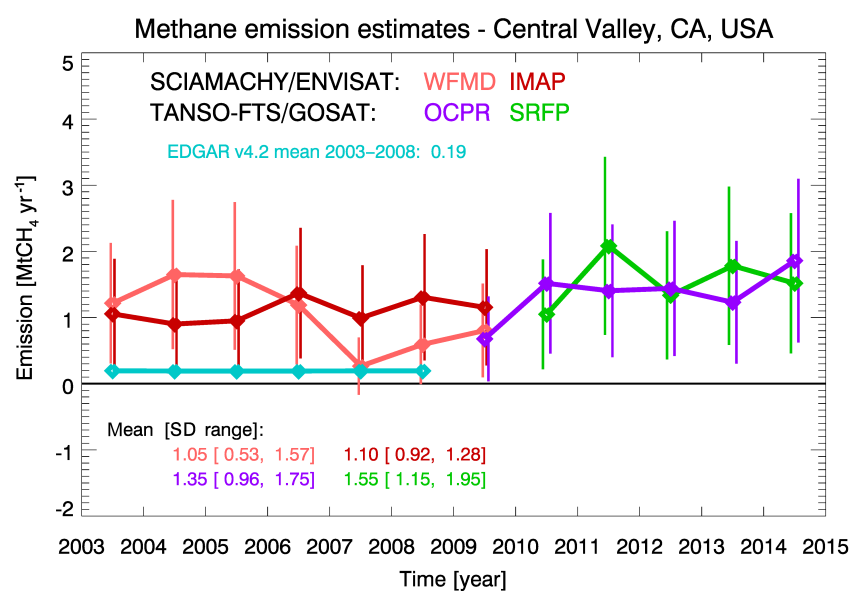

Figure 18. Methane emission estimates for Central Valley area in California, USA, as defined for this study (see Fig. 17 and Table 2). The blue line shows the EDGAR v4.2 (annual) anthropogenic methane emissions as computed for the Central Valley source region.

(13 subregions) top-down estimates of California's $\mathrm{CH}_{4}$ emissions using in situ tower data. They report for their region $\mathrm{R} 12$, which is similar but not exactly identical to the area chosen in our assessment, emissions of 0.85 and $0.94 \mathrm{MtCH}_{4} \mathrm{yr}^{-1}$ (depending on a priori assumptions) based on inversion of in situ tower data (see their Table 5 reporting methane emissions in $\mathrm{TgCO}_{2}$ eq computed assuming a global warming potential of $21 \mathrm{gCO}_{2} \mathrm{eqCH}_{4} / \mathrm{gCH}_{4}$ ), which is a factor of $3.6(=17.89 / 5.01$, see their Table 5) higher than EDGAR v4.2.

Jeong et al. (2014) also studied this region and presented a new spatially resolved bottom-up inventory of methane for 2010 focusing on methane emissions from petroleum production and natural gas systems in California. They showed that the region around Bakersfield is a major oil and gas production and transmission region in California (see their Fig. 1) and they found that their emission estimates are 37 times higher for the petroleum and gas production sectors compared to official California bottom-up inventories.

Our results corroborate the findings of these independent studies that inventory emissions are underestimated in this region. However, we acknowledge the large uncertainty of our estimated annual emissions and cannot rule out that our emission estimates are overestimated e.g. due to possible methane accumulation in the southern part of the Central Valley.

\subsection{Azerbaijan and Turkmenistan}

Azerbaijan and Turkmenistan are located next to the Caspian Sea (to the west and to the east, respectively) and both countries are important oil and gas producers. Azerbaijan and Turkmenistan are clearly visible as methane emission hotspots in satellite $\mathrm{XCH}_{4}$ data sets (Figs. 1, 19).
Figure 19 shows 2004 SCIAMACHY WFMD $\mathrm{XCH}_{4}$ in the Azerbaijan/Turkmenistan area and emission database results from EDGAR v4.2 (Fig. 19d), CAMS v10-S1NOAA (Fig. 19e), and CAMS v10-S1SCIA (Fig. 19f). In contrast to the results discussed in the previous section, the assimilation of SCIAMACHY data in the TM5-4DVAR assimilation system enhances the emissions around Azerbaijan/Turkmenistan (compare Fig. 19e with f).

Figure 20 shows Azerbaijan methane emissions as obtained with our inversion method compared to EDGAR v4.2 emissions. As can be seen, the satellite-derived emissions are consistent with EDGAR. Here the CH4_GOS_SRFP product is not shown. Due to the sparse spatial sampling of this product the interannual variability is dominated by year-to-year sampling differences. Azerbaijan is surrounded by many other methane emission areas and, therefore, not a well-isolated emission hotspot, i.e. not ideal for our inversion method. The impact of this is largest for the CH4_GOS_SRFP product, which is a sparse data set as the underlying FP retrieval algorithm requires strict quality filtering.

Turkmenistan is much larger in size compared to Azerbaijan (see Fig. 19) but also not a well-isolated emission hotspot. The results for Turkmenistan are shown in Fig. 21. Here the mean values of all estimated emissions are positive (in contrast to Azerbaijan), indicating that the methane concentration over Turkmenistan is higher than its surrounding for all years and all four satellite products. The mean values of the derived emissions are in the range 1.85$2.08 \mathrm{MtCH}_{4} \mathrm{yr}^{-1}$, which is about $50 \%$ larger compared to EDGAR (1.33 $\mathrm{MtCH}_{4} \mathrm{yr}^{-1}$ ). This may be due to an underestimation of Turkmenistan's oil- and gas-related methane emissions in EDGAR, but one also has to note the large uncertainty of our satellite-derived annual emissions. Furthermore, Turkmenistan is not an ideally isolated methane hotspot, although the Azerbaijan results do not indicate that this is necessarily a significant issue. Note also that mountains are located southward and eastward of Turkmenistan and this may contribute to a local accumulation (trapping) of atmospheric methane (resulting in an overestimation of our estimated emissions) and may explain why the elevated methane over Turkmenistan as shown in Fig. 19 is well correlated with the country boundaries. Clearly, more studies are needed to clarify this but this likely requires much more complex inversion methods than the one used in this study (e.g. similar to those presented in Wecht et al., 2014a, and Gentner et al., 2014).

\section{Summary and conclusions}

We have presented a simple but very fast method to estimate methane surface emissions of areas showing elevated atmospheric methane concentrations relative to their surrounding areas ("methane hotspots") in satellite-derived $\mathrm{XCH}_{4}$ maps, 

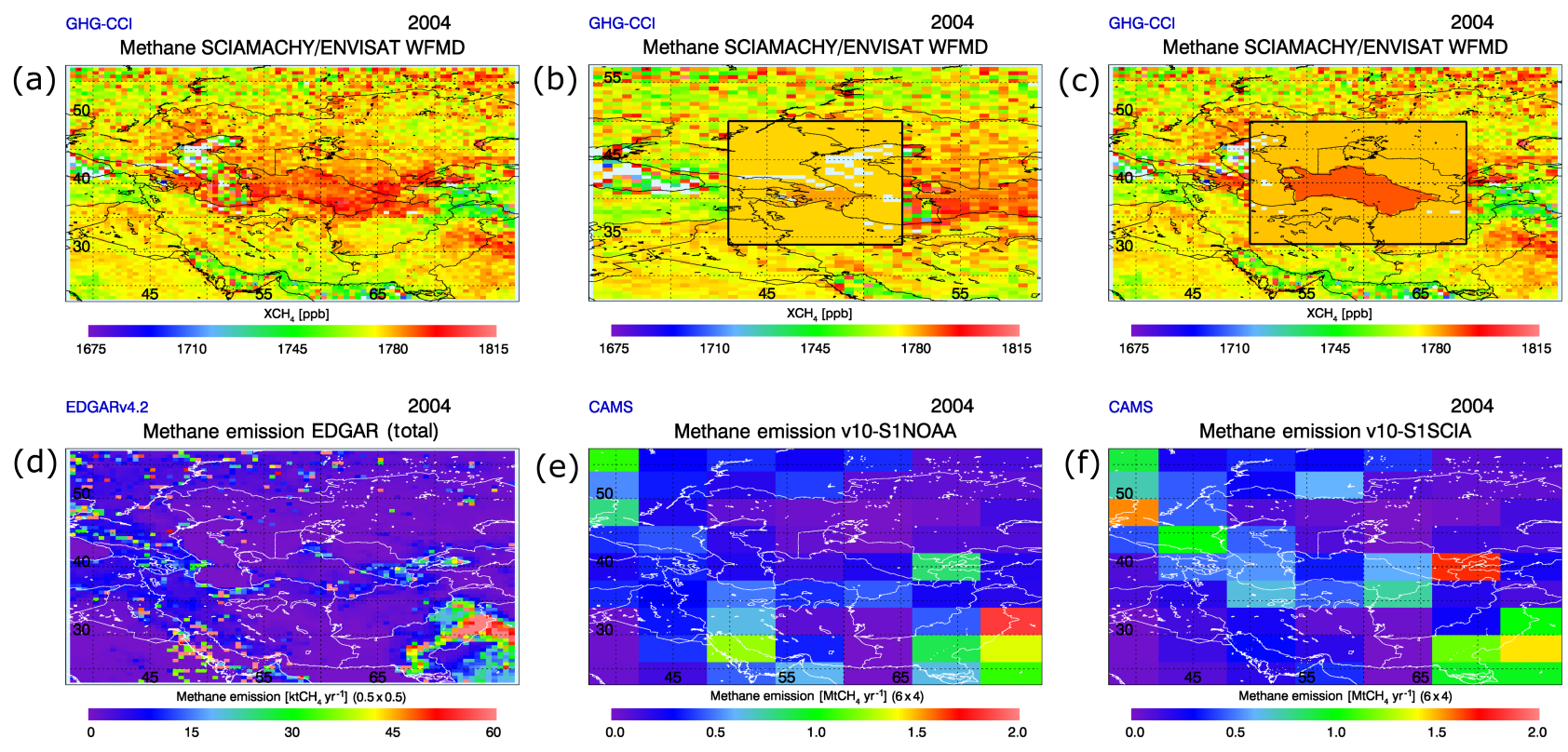

Figure 19. (a) SCIAMACHY WFMD year $2004 \mathrm{XCH}_{4}$ in and around Azerbaijan and Turkmenistan (resolution $0.5^{\circ} \times 0.5^{\circ}$ ). (b) As (a) but showing the Azerbaijan source region (entire country of Azerbaijan) and the default background region (rectangle) (please note that this map is shifted relative to all other maps shown in this figure to place Azerbaijan in the centre of the map). (c) As (a) but showing the Turkmenistan source and default background regions. (d) EDGAR v4.2 year 2004 total anthropogenic methane emissions (at $0.5^{\circ} \times 0.5^{\circ}$ resolution). (e) CAMS year 2004 total anthropogenic and natural methane emissions based on assimilation of NOAA data (at $6^{\circ} \times 4^{\circ}$ resolution). (f) As (e) but with additional assimilation of SCIAMACHY IMAP $\mathrm{XCH}_{4}$.

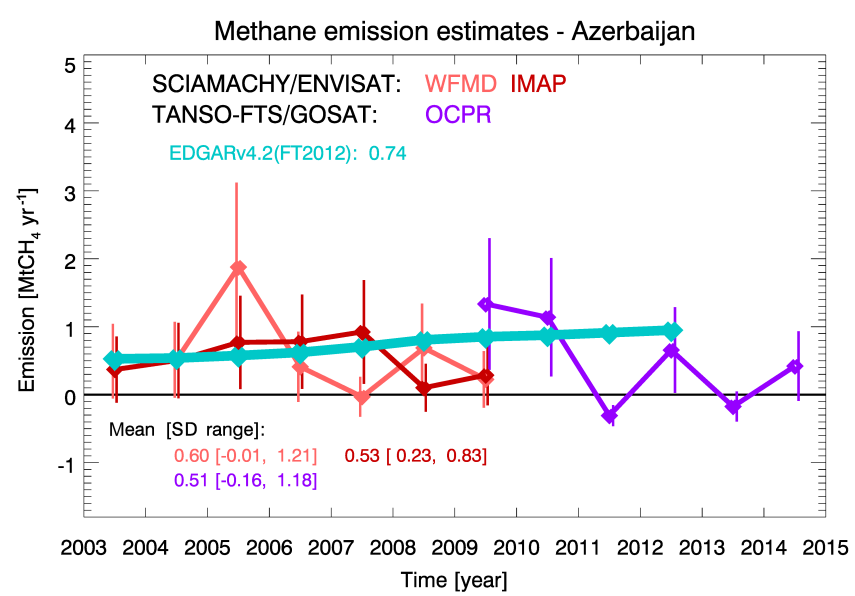

Figure 20. Annual methane emission estimates for Azerbaijan (see also Fig. 19). The blue line shows the EDGAR v4.2 (FT2012) annual emissions for Azerbaijan.

especially in those derived from SCIAMACHY/ENVISAT. The described "inversion method", which is a simple mass balance method, is applicable to time-averaged $\mathrm{XCH}_{4}$ data sets (as complex spatio-temporal $\mathrm{XCH}_{4}$ variations due to varying meteorological conditions cannot be considered by our method). Here we focus on annual $\mathrm{XCH}_{4}$ maps to derive annual emissions. The method is based on a direct conversion of a localized methane enhancement (relative to its surround-

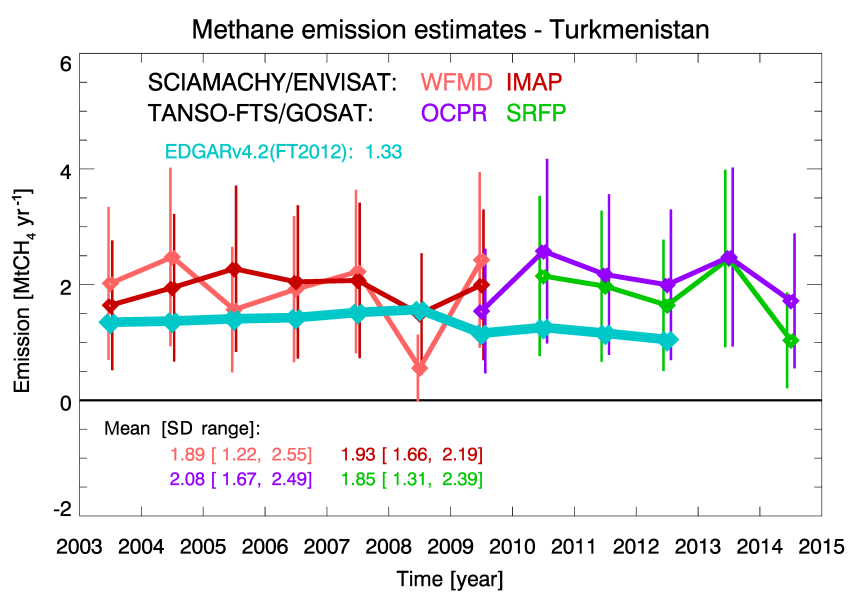

Figure 21. Annual methane emission estimates for Turkmenistan (see also Fig. 19). The blue line shows the EDGAR v4.2 (FT2012) annual emissions for Turkmenistan.

ing area) using a conversion factor, which mainly depends on the size of the source region of interest. The method is calibrated using global two-dimensional methane emission maps and corresponding global two-dimensional $\mathrm{XCH}_{4}$ maps generated from Copernicus Atmospheric Monitoring Service (CAMS) three-dimensional atmospheric methane fields. A limitation of our method is its quite large uncertainty. We estimate that the uncertainty of the method is about $80 \%$ for 
annual emissions around $1 \mathrm{MtCH}_{4} \mathrm{yr}^{-1}$ but with better relative uncertainty for larger emissions (down to about $50 \%$ for very large emissions, i.e. several $\mathrm{MtCH}_{4} \mathrm{yr}^{-1}$ ).

The inversion method has been tested by applying it to a high-resolution methane data set covering the USA, which has been computed with GEOS-Chem. We retrieve methane emissions for several areas where the GEOS-Chem data set shows elevated $\mathrm{XCH}_{4}$ compared to their surrounding areas. We found that the estimated emissions are typically $40 \%$ lower compared to the emissions used in the model (which are the known, i.e. "true" emissions of this simulation experiment). The true emissions are (with one exception) located within the $1 \sigma$ uncertainty range of our emission estimates. From theoretical considerations we expect that our method tends to underestimate emissions, i.e. that it provides rather conservative emission estimates. To what extent the $40 \%$ value depends on the model used and on its characteristics (such as spatio-temporal resolution) needs to be investigated in the future by using additional models.

We applied our method to an ensemble of satellite $\mathrm{XCH}_{4}$ data products using two products from SCIAMACHY/ENVISAT and two products from TANSOFTS/GOSAT as made available via the GHG-CCI project website (http://www.esa-ghg-cci.org/) of ESA's CCI. These products cover the time period 2003-2014.

The inversion method as applied to real satellite data has been applied to four source areas. Two of the source areas are located in the USA (the Four Corners area located in the south-western USA and the southern part of the Central Valley, i.e. the region around Bakersfield and Fresno, in California) and the two other source regions are Azerbaijan and Turkmenistan, which are both important oil- and gas-producing countries. All four regions clearly show elevated methane relative to their surrounding in satellitederived $\mathrm{XCH}_{4}$ maps.

For Four Corners we obtain annual emissions in the range $0.42-0.57 \mathrm{MtCH}_{4} \mathrm{yr}^{-1}$ in agreement with published values. For Azerbaijan our estimates are on average close to the total anthropogenic methane emissions of Azerbaijan as given in the EDGARv4.2 (FT2012) emission inventory but for Turkmenistan we obtain about $50 \%$ higher emissions on average albeit with large uncertainty. Further study is needed to investigate if this is due to an underestimation of Turkmenistan's oil- and gas-related emissions in EDGAR.

For the region around Bakersfield located in the Central Valley of California, a region of significant oil and gas production and large expected methane emissions from dairy and livestock operations, we obtain mean emissions in the range $1.05-1.55 \mathrm{MtCH}_{4} \mathrm{yr}^{-1}$, depending on satellite data product. This is about a factor of 5-8 higher than the total methane emissions as given in the EDGAR v4.2 inventory but of similar magnitude as reported in Jeong et al. (2013) $\left(0.85-0.94 \mathrm{MtCH}_{4} \mathrm{yr}^{-1}\right)$ based on inverse modelling of tower measurements. Our findings also corroborate published results from CalNex campaign aircraft observa- tions during May to June 2010 (Wecht et al., 2014b) showing high methane concentrations over the southern part of the Central Valley, in the San Joaquin Valley, compared to other parts of California and concluding that EDGAR emissions in this area need to be scaled with factors up to around 5. They conclude that livestock emissions in EDGAR are significantly underestimated. Another more recent study (Joeng et al., 2014) presented a new bottom-up methane inventory for the year 2010 for California, concluding that their emissions are 3-7 times higher compared to official California bottom-up inventories for the petroleum and natural gas production sectors. Also the new US Environmental Protection Agency (EPA) methane emission inventory (Maasakkers et al., 2016) shows significantly larger emission in the area around Bakersfield compared to EDGAR v4.2. Nevertheless, our results need to be interpreted with care as the uncertainty of our annual emission estimates is large and we cannot entirely rule out that our estimates are somewhat overestimated e.g. due to possible methane accumulation in the valley.

We recommend further studies to investigate in more detail the reported discrepancy of the satellite-derived emissions with emission inventories in particular for Turkmenistan but possibly also for the southern part of the Central Valley in California. We also recommend using ensembles of satellite products as done in this study in order to determine to what extent key findings depend on the algorithmic choices which have to be made when developing a retrieval algorithm used to generate a particular $\mathrm{XCH}_{4}$ data product and to what extent the findings depend on the particular satellite instrument used to derive the results. More detailed assessments likely require the use of much more complex approaches compared to the simple method uses in this study. Nevertheless, simple and fast approaches also have a role to play as they permit to perform quick assessments on possible discrepancies with respect to emission inventories or other data sets and can also be used for plausibility checks for more complex approaches.

It is also important to monitor the emissions of major methane source regions in the future. In this context the upcoming satellite mission Sentinel-5 Precursor (S5P) will potentially play an important role. S5P is planned to be launched in the middle of 2017 and will deliver $\mathrm{XCH}_{4}$ at high spatial resolution ( $7 \mathrm{~km}$ at nadir) and with good spatial coverage $(2600 \mathrm{~km}$ swath width, i.e. daily coverage) (Veefkind et al., 2012; Butz et al., 2012) resulting in methane observations with dense spatio-temporal coverage, which is a significant advantage for methane hotspot detection and related emission quantification compared to the past and present satellites used in this study.

The longer-term objective of releasing an observing system comprising instruments with the performance of CarbonSat within a CarbonSat constellation (Bovensmann et al., 2010; Velazco et al., 2011; Buchwitz et al., 2013; Pillai et al., 2016; ESA, 2015) is currently being discussed by the ESA and European Union (EU) representatives within the Copernicus program focusing on $\mathrm{CO}_{2}$ (e.g. Ciais et al., 2015). Such 
a system will provide, when coupled with sparse but accurate ground-based systems, the objective evidence about the global $\mathrm{CH}_{4}$ and $\mathrm{CO}_{2}$ surface fluxes needed for verification and monitoring of emissions and to improve our knowledge on natural carbon fluxes.

Data availability. The satellite data products are available from the GHG-CCI project website http://www.esa-ghg-cci.org/ (please click on CRDP (Data)). On that website older and newer product versions are also available. The version numbers of the products used for this paper are listed in Table 1.

Competing interests. The authors declare that they have no conflict of interest.

Acknowledgements. This study has been funded by ESA via the GHG-CCI project of ESA's Climate Change Initiative (CCI). Jens Heymann and Robert J. Parker are also funded by an ESA Living Planet Fellowship. The University of Leicester GOSAT retrievals used the ALICE High Performance Computing Facility at the University of Leicester. We thank ESA/DLR for providing us with SCIAMACHY Level 1 data products and JAXA for GOSAT Level 1B data. We also thank ESA for making these GOSAT products available via the ESA Third Party Mission archive. The satellite $\mathrm{XCH}_{4}$ data products have been obtained from the ESA project GHG-CCI website (http://www.esa-ghg-cci.org/) maintained by University of Bremen. Methane emissions and corresponding atmospheric methane fields have been obtained from the Copernicus Atmospheric Monitoring Service (CAMS) website (https://atmosphere.copernicus.eu/; we thank P. Bergamaschi, European Commission Joint Research Centre (EC-JRC), Institute for Environment and Sustainability (IES), Climate Change Unit, Ispra, Italy, for providing us with earlier versions of this data set). We thank the EDGAR team for making available EDGAR anthropogenic methane emission inventory data (obtained from http://edgar.jrc.ec.europa.eu/gallery.php?release= v42\&substance $=\mathrm{CH} 4 \&$ sector $=$ TOTALS). In particular, we thank G. Janssens-Maenhout from the EC-JRC EDGAR team for helpful comments. We also thank USGS for making available the GTOPO30 digital elevation model (DEM) database (obtained from https://lta.cr.usgs.gov/GTOPO30) and ECMWF for meteorological data (obtained from www.ecmwf.int/). Last but not least we thank two anonymous referees for their critical reviews of the ACPD version of this paper.

The article processing charges for this open-access publication were covered by the University of Bremen.

Edited by: R. McLaren

Reviewed by: two anonymous referees

\section{References}

Alexe, M., Bergamaschi, P., Segers, A., Detmers, R., Butz, A., Hasekamp, O., Guerlet, S., Parker, R., Boesch, H., Frankenberg, C., Scheepmaker, R. A., Dlugokencky, E., Sweeney, C., Wofsy, S. C., and Kort, E. A.: Inverse modeling of $\mathrm{CH}_{4}$ emissions for 2010-2011 using different satellite retrieval products from GOSAT and SCIAMACHY, Atmos. Chem. Phys., 15, 113133, doi:10.5194/acp-15-113-2015, 2015.

Bao, J.-W., Michelson, S. A., Persson, P. O. G., Djalalova, I. V., and Wilczak, J. M.: Observed and WRF-Simulated Low-Level Winds in a High-Ozone Episode during the Central California Ozone Study, J. Appl. Meteorol. Climatol., 47, 2372-2394, doi:10.1175/2008JAMC1822.1, 2008.

Bergamaschi, P., Frankenberg, C., Meirink, J. F., Krol, M., Dentener, F., Wagner, T., Platt, U., Kaplan, J. O., Körner, S., Heimann, M., Dlugokencky, E., and Goede, A. P. H.: Satellite chartography of atmospheric methane from SCIAMACHY onboard ENVISAT: 2. Evaluation based on inverse model simulations, J. Geophys. Res., 112, D02304, doi:10.1029/2006JD007268, 2007.

Bergamaschi, P., Frankenberg, C., Meirink, J. F., Krol, M., Villani, M. G., Houweling, S., Dentener, F., Dlugokencky, E. J., Miller, J. B., Gatti, L. V., Engel, A., and Levin, I.: Inverse modeling of global and regional $\mathrm{CH}_{4}$ emissions using SCIAMACHY satellite retrievals, J. Geophys. Res., 114, D22301, doi:10.1029/2009JD01228, 2009.

Bergamaschi, P., Houweling, H., Segers, A., Krol, M., Frankenberg, C., Scheepmaker, R. A., Dlugokencky, E., Wofsy, S. C., Kort, E. A., Sweeney, C., Schuck, T., Brenninkmeijer, C., Chen, H., Beck, V., and Gerbig, C.: Atmospheric $\mathrm{CH}_{4}$ in the first decade of the 21 st century: Inverse modeling analysis using SCIAMACHY satellite retrievals and NOAA surface measurements, J. Geophys. Res., 118, 7350-7369, doi:10.1002/jrgd.5048, 2013.

Bloom, A. A., Palmer, P. I., Fraser, A., Reay, D. S., and Frankenberg, C.: Large-scale controls of methanogenesis inferred from methane and gravity spaceborne data, Science, 327, 322-325, doi:10.1126/science.1175176, 2010.

Bovensmann, H., Burrows, J. P., Buchwitz, M., Frerick, J., Noël, S., Rozanov, V. V., Chance, K. V., and Goede, A. H. P.: SCIAMACHY - Mission objectives and measurement modes, J. Atmos. Sci., 56, 127-150, 1999.

Bovensmann, H., Buchwitz, M., Burrows, J. P., Reuter, M., Krings, T., Gerilowski, K., Schneising, O., Heymann, J., Tretner, A., and Erzinger, J.: A remote sensing technique for global monitoring of power plant $\mathrm{CO}_{2}$ emissions from space and related applications, Atmos. Meas. Tech., 3, 781-811, doi:10.5194/amt-3-781-2010, 2010.

Buchwitz, M., Rozanov, V. V., and Burrows, J. P.: A near-infrared optimized DOAS method for the fast global retrieval of atmospheric $\mathrm{CH}_{4}, \mathrm{CO}, \mathrm{CO}_{2}, \mathrm{H}_{2} \mathrm{O}$, and $\mathrm{N}_{2} \mathrm{O}$ total column amounts from SCIAMACHY Envisat-1 nadir radiances, J. Geophys. Res., 105, 15231-15245, 2000.

Buchwitz, M., de Beek, R., Burrows, J. P., Bovensmann, H., Warneke, T., Notholt, J., Meirink, J. F., Goede, A. P. H., Bergamaschi, P., Körner, S., Heimann, M., and Schulz, A.: Atmospheric methane and carbon dioxide from SCIAMACHY satellite data: initial comparison with chemistry and transport models, Atmos. Chem. Phys., 5, 941-962, doi:10.5194/acp-5-941-2005, 2005. 
Buchwitz, M., Reuter, M., Bovensmann, H., Pillai, D., Heymann, J., Schneising, O., Rozanov, V., Krings, T., Burrows, J. P., Boesch, H., Gerbig, C., Meijer, Y., and Löscher, A.: Carbon Monitoring Satellite (CarbonSat): assessment of atmospheric $\mathrm{CO}_{2}$ and $\mathrm{CH}_{4}$ retrieval errors by error parameterization, Atmos. Meas. Tech., 6, 3477-3500, doi:10.5194/amt-6-3477-2013, 2013.

Buchwitz, M., Reuter, M., Schneising, O., Boesch, H., Guerlet, S., Dils, B., Aben, I., Armante, R., Bergamaschi, P., Blumenstock, T., Bovensmann, H., Brunner, D., Buchmann, B., Burrows, J. P., Butz, A., Chédin, A., Chevallier, F., Crevoisier, C. D., Deutscher, N. M., Frankenberg, C., Hase, F., Hasekamp, O. P., Heymann, J., Kaminski, T., Laeng, A., Lichtenberg, G., De Mazière, M., Noël, S., Notholt, J., Orphal, J., Popp, C., Parker, R., Scholze, M., Sussmann, R., Stiller, G. P., Warneke, T., Zehner, C., Bril, A., Crisp, D., Griffith, D. W. T., Kuze, A., O’Dell, C., Oshchepkov, S., Sherlock, V., Suto, H., Wennberg, P., Wunch, D., Yokota, T., and Yoshida, Y.: The Greenhouse Gas Climate Change Initiative (GHG-CCI): comparison and quality assessment of near-surface-sensitive satellite-derived $\mathrm{CO}_{2}$ and $\mathrm{CH}_{4}$ global data sets, Remote Sens. Environ., 162, 344-362, doi:10.1016/j.rse.2013.04.024, 2015.

Buchwitz, M., Dils, B., Boesch, H., Crevoisier, C., Detmers, D., Frankenberg, C., Hasekamp, O., Hewson, W., Laeng, A., Noël, S., Notholt, J., Parker, R., Reuter, M., and Schneising, O.: ESA Climate Change Initiative (CCI) Product Validation and Intercomparison Report (PVIR) for the Essential Climate Variable (ECV) Greenhouse Gases (GHG) for data set Climate Research Data Package No. 3 (CRDP\#3), Version 4.0, http://www. esa-ghg-cci.org/?q=webfm_send/300 last access: 24 February 2016, 2016a.

Buchwitz, M., Reuter, M., Schneising, O., Hewson, W., Detmers, R. G., Boesch, H., Hasekamp, O. P., Aben, I., Bovensmann, H., Burrows, J. P., Butz, A., Chevallier, F., Dils, B., Frankenberg, C., Heymann, J., Lichtenberg, G., De Mazière, M., Notholt, J., Parker, R., Warneke, T., Zehner, C., Griffith, D. W. T., Deutscher, N. M., Kuze, A., Suto, H., and Wunch, D.:, Global satellite observations of column-averaged carbon dioxide and methane: The GHG-CCI $\mathrm{XCO}_{2}$ and $\mathrm{XCH}_{4} \mathrm{CRDP} 3$ data, Remote Sens. Environ., in press, 20 pp., doi:10.1016/j.rse.2016.12.027, 2016b.

Burrows, J. P., Hölzle, E., Goede, A. P. H., Visser, H., and Fricke, W.: SCIAMACHY - Scanning Imaging Absorption Spectrometer for Atmospheric Chartography, Acta Astronaut., 35, 445-451, doi:10.1016/0094-5765(94)00278-t, 1995.

Butz, A., Hasekamp, O. P., Frankenberg, C., Vidot, J., and Aben, I.: $\mathrm{CH}_{4}$ retrievals from space-based solar backscatter measurements: Performance evaluation against simulated aerosol and cirrus loaded scenes, J. Geophys. Res., 115, D24302, doi:10.1029/2010JD014514, 2010.

Butz, A., Guerlet, S., Hasekamp, O., Schepers, D., Galli, A., Aben, I., Frankenberg, C., Hartmann, J.-M., Tran, H., Kuze, A., Keppel-Aleks, G., Toon, G., Wunch, D., Wennberg, P., Deutscher, N., Griffith, D., Macatangay, R., Messerschmidt, J., Notholt, J., and Warneke, T.: Toward accurate $\mathrm{CO}_{2}$ and $\mathrm{CH}_{4}$ observations from GOSAT, Geophys. Res. Lett., 38, L14812, doi:10.1029/2011GL047888, 2011.

Butz, A., Galli, A., Hasekamp, O., Landgraf, J., Tol, P., and Aben, I.: Remote Sensing of Environment, TROPOMI aboard Sentinel-5 Precursor: Prospective performance of $\mathrm{CH}_{4}$ retrievals for aerosol and cirrus loaded atmospheres, Remote Sens. Environ., 120, 267-276, doi:10.1016/j.rse.2011.05.030, 2012.

Chevallier, F., Buchwitz, M., Bergamaschi, P., Houweling, S., van Leeuwen, T., and Palmer, P. I.: User Requirements Document for the GHG-CCI project of ESA's Climate Change Initiative, version 2 (URDv2), http://www.esa-ghg-cci.org/?q=webfm_send/ 173), last acces: 28 August 2014b.

Chevallier, F., Alexe, M., Bergamaschi, P., Brunner, D., Feng, L., Houweling, S., Kaminski, T., Knorr, W., van Leeuwen, T. T., Marshall, J., Palmer, P. I., Scholze, M., Sundström, A.-M., and Voßbeck, M.: ESA Climate Change Initiative (CCI) Climate Assessment Report (CAR) for Climate Research Data Package No. 3 (CRDP\#3) of the Essential Climate Variable (ECV) Greenhouse Gases (GHG), Version 3, 3 May 2016, 94 pp., http://www. esa-ghg-cci.org/?q=webfm_send/318, last access: 3 May 2016.

Ciais, P., Dolman, A. J., Bombelli, A., Duren, R., Peregon, A., Rayner, P. J., Miller, C., Gobron, N., Kinderman, G., Marland, G., Gruber, N., Chevallier, F., Andres, R. J., Balsamo, G., Bopp, L., Bréon, F.-M., Broquet, G., Dargaville, R., Battin, T. J., Borges, A., Bovensmann, H., Buchwitz, M., Butler, J., Canadell, J. G., Cook, R. B., DeFries, R., Engelen, R., Gurney, K. R., Heinze, C., Heimann, M., Held, A., Henry, M., Law, B., Luyssaert, S., Miller, J., Moriyama, T., Moulin, C., Myneni, R. B., Nussli, C., Obersteiner, M., Ojima, D., Pan, Y., Paris, J.-D., Piao, S. L., Poulter, B., Plummer, S., Quegan, S., Raymond, P., Reichstein, M., Rivier, L., Sabine, C., Schimel, D., Tarasova, O., Valentini, R., Wang, R., van der Werf, G., Wickland, D., Williams, M., and Zehner, C.: Current systematic carbon-cycle observations and the need for implementing a policy-relevant carbon observing system, Biogeosciences, 11, 3547-3602, doi:10.5194/bg-113547-2014, 2014.

Ciais, P., Crisp, D., Denier van der Gon, H., Engelen, R., JanssensMaenhout, G., Heimann, M., Rayner, P., and Scholze, M.: Towards a European Operational Observing System to Monitor Fossil $\mathrm{CO}_{2}$ emissions - Final Report from the expert group, 68 pp., http://www.copernicus.eu/main/ (last access: 1 March 2016), 2015.

Cressot, C., Chevallier, F., Bousquet, P., Crevoisier, C., Dlugokencky, E. J., Fortems-Cheiney, A., Frankenberg, C., Parker, R. Pison, I., Scheepmaker, R. A., Montzka, S. A., Krummel, P. B., Steele, L. P., and Langenfelds, R. L.: On the consistency between global and regional methane emissions inferred from SCIAMACHY, TANSO-FTS, IASI and surface measurements, Atmos. Chem. Phys., 14, 577-592, doi:10.5194/acp-14-577-2014, 2014

Dee, D. P., Uppala, S. M., Simmons, A. J., Berrisford, P., Poli, P., Kobayashi, S., Andrae, U., Balmaseda, M. A., Balsamo, G., Bauer, P., Bechtold, P., Beljaars, A. C. M., van de Berg, L., Bidlot, J., Bormann, N., Delsol, C., Dragani, R., Fuentes, M., Geer, A. J., Haimberger, L., Healy, S. B., Hersbach, H., Hólm, E. V., Isaksen, L., Kållberg, P., Köhler, M., Matricardi, M., McNally, A. P., Monge-Sanz, B. M., Morcrette, J.-J., Park, B.-K., Peubey, C., de Rosnay, P., Tavolato, C., Thépaut, J.-N., and Vitart, F.: The ERA-Interim reanalysis: configuration and performance of the data assimilation system, Q. J. R. Meteorol. Soc., 137, 553-597, doi:10.1002/qj.828, 2011.

Dils, B., Buchwitz, M., Reuter, M., Schneising, O., Boesch, H., Parker, R., Guerlet, S., Aben, I., Blumenstock, T., Burrows, J. P., Butz, A., Deutscher, N. M., Frankenberg, C., Hase, F., Hasekamp, O. P., Heymann, J., De Maziere, M., Notholt, J., Suss- 
mann, R., Warneke, T., Griffith, D., Sherlock, V., and Wunch, D.: The Greenhouse Gas Climate Change Initiative (GHG-CCI): comparative validation of GHG-CCI SCIAMACHY/ENVISAT and TANSO-FTS/GOSAT $\mathrm{CO}_{2}$ and $\mathrm{CH}_{4}$ retrieval algorithm products with measurements from the TCCON, Atmos. Meas. Tech., 7, 1723-1744, doi:10.5194/amt-7-1723-2014, 2014.

ESA: Report for Mission Selection: CarbonSat, ESA SP1330/1 (2 volume series), Noordwijk, The Netherlands, available at: http://esamultimedia.esa.int/docs/EarthObservation/ SP1330-1_CarbonSat.pdf (last access: 1 March 2016), 2015.

Frankenberg, C., Meirink, J. F., van Weele, M., Platt, U., and Wagner, T.: Assessing methane emissions from global space-borne observations, Science, 308, 1010-1014, doi:10.1126/science.1106644, 2005.

Frankenberg, C., Meirink, J. F., Bergamaschi, P., Goede, A. P. H., Heimann, M., Körner, S., Platt, U., van Weele, M., and Wagner, T.: Satellite chartography of atmospheric methane from SCIAMACHY onboard ENVISAT: Analysis of the years 2003 and 2004, J. Geophys. Res., 111, D07303, doi:10.1029/2005JD006235, 2006.

Frankenberg, C., Warneke, T., Butz, A., Aben, I., Hase, F., Spietz, P., and Brown, L. R.: Pressure broadening in the $2 v_{3}$ band of methane and its implication on atmospheric retrievals, Atmos. Chem. Phys., 8, 5061-5075, doi:10.5194/acp-8-5061-2008, 2008a.

Frankenberg, C., Bergamaschi, P., Butz, A., Houweling, S., Meirink, J. F., Notholt, J., Petersen, A. K., Schrijver, H., Warneke, T., and Aben, I.: Tropical methane emissions: A revised view from SCIAMACHY onboard ENVISAT, Geophys. Res. Lett., 35, L15811, doi:10.1029/2008GL034300, 2008b.

Frankenberg, C., Aben, I., Bergamaschi, P., Dlugokencky, E. J., van Hees, R., Houweling, S., van der Meer, P., Snel, R., and Tol, P.: Global column-averaged methane mixing ratios from 2003 to 2009 as derived from SCIAMACHY: Trends and variability, J. Geophys. Res., 116, D04302, doi:10.1029/2010JD014849, 2011.

Frankenberg, C., Thorpe, A. K., Thompson, D. R., Hulley, G., Kort, E. A., Vanceb, N., Borchardt, J., Krings, T., Gerilowski, K., Sweeney, C., Conley, S., Bueb, B. D.,Aubrey, A. D., Hook, S., and Green, R. O.: Airborne methane remote measurements reveal heavytail flux distribution in Four Corners region, Proc. Natl. Acad. Sci. USA (PNAS), 6 pp., http://www.pnas.org/content/ early/2016/08/10/1605617113, last access: 10 September 2016.

Fraser, A., Palmer, P. I., Feng, L., Boesch, H., Cogan, A., Parker, R., Dlugokencky, E. J., Fraser, P. J., Krummel, P. B., Langenfelds, R. L., O'Doherty, S., Prinn, R. G., Steele, L. P., van der Schoot, M., and Weiss, R. F.: Estimating regional methane surface fluxes: the relative importance of surface and GOSAT mole fraction measurements, Atmos. Chem. Phys., 13, 5697-5713, doi:10.5194/acp-13-5697-2013, 2013.

Gentner, D. R., Ford, T. B., Guha, A., Boulanger, K., Brioude, J., Angevine, W. M., de Gouw, J. A., Warneke, C., Gilman, J. B., Ryerson, T. B., Peischl, J., Meinardi, S., Blake, D. R., Atlas, E., Lonneman, W. A., Kleindienst, T. E., Beaver, M. R., St. Clair, J. M., Wennberg, P. O., VandenBoer, T. C., Markovic, M. Z., Murphy, J. G., Harley, R. A., and Goldstein, A. H.: Emissions of organic carbon and methane from petroleum and dairy operations in California's San Joaquin Valley, Atmos. Chem. Phys., 14, 4955-4978, doi:10.5194/acp-14-4955-2014, 2014.
Guha, A., Gentner, D. R., Weber, R. J., Provencal, R., and Goldstein, A. H.: Source apportionment of methane and nitrous oxide in California's San Joaquin Valley at CalNex 2010 via positive matrix factorization, Atmos. Chem. Phys., 15, 12043-12063, doi:10.5194/acp-15-12043-2015, 2015.

Hollmann, R., Merchant, C. J., Saunders, R., Downy, C., Buchwitz, M., Cazenave, A., Chuvieco, E., Defourny, P., de Leeuw, G. , Forsberg, R., Holzer-Popp, T., Paul, F., Sandven, S., Sathyendranath, S., van Roozendael, M., and Wagner, W.: The ESA Climate Change Initiative: satellite data records for essential climate variables, Bull. Am. Meteor. Soc., doi:10.1175/BAMS-D11-00254.1 (last access: 1 February 2014), 2013.

Houweling, S., Krol, M., Bergamaschi, P., Frankenberg, C., Dlugokencky, E. J., Morino, I., Notholt, J., Sherlock, V., Wunch, D., Beck, V., Gerbig, C., Chen, H., Kort, E. A., Röckmann, T., and Aben, I.: A multi-year methane inversion using SCIAMACHY, accounting for systematic errors using TCCON measurements, Atmos. Chem. Phys., 14, 3991-4012, doi:10.5194/acp-14-39912014, 2014.

Houweling, S., Bergamaschi, P., Chevallier, F., Heimann, M., Kaminski, T., Krol, M., Michalak, A. M., and Patra, P.: Global inverse modeling of $\mathrm{CH}_{4}$ sources and sinks: an overview of methods, Atmos. Chem. Phys., 17, 235-256, doi:10.5194/acp-17-2352017, 2017.

IPCC: Climate Change 2013: The Physical Science Basis, Working Group I Contribution to the Fifth Assessment Report of the Intergovernmental Report on Climate Change, http://www.ipcc.ch/ report/ar5/wg1/ (last access: 15 March 2014), 2013.

Jacob, D. J., Turner, A. J., Maasakkers, J. D., Sheng, J., Sun, K., Liu, X., Chance, K., Aben, I., McKeever, J., and Frankenberg, C.: Satellite observations of atmospheric methane and their value for quantifying methane emissions, Atmos. Chem. Phys., 16, 14371-14396, doi:10.5194/acp-2016-14371-2016, 2016.

Jeong, S., Hsu, Y.-K., Andrews, A. E., Bianco, L., Vaca, P., Wilczak, J. M., and Fischer, M. L.: A multitower measurement network estimate of California's methane emissions, J. Geophys. Res. Atmos., 118, 11339-11351, doi:10.1002/jgrd.50854, 2013.

Jeong, S., Millstein, D., and Fischer, M. L.: Spatially Explicit Methane Emissions from Petroleum Production and the Natural Gas System in California, Environ. Sci. Technol., 48, 59825990, doi:10.1021/es4046692, 2014.

Kirschke, S., Bousquet, P., Ciais, P. et al.: Three decades of global methane sources and sinks, Nat. Geosci., 6, 813-823, doi:10.1038/ngeo1955, 2013.

Kort, E. A., Frankenberg, C., Costigan, K. R., Lindenmaier, R., Dubey, M. K., and Wunch, D.: Four corners: The largest US methane anomaly viewed from space, Geophys. Res. Lett., 41, 6898-6903, doi:10.1002/2014GL061503, 2014.

Kuze, A., Suto, H., Nakajima, M., and Hamazaki, T.: Thermal and near infrared sensor for carbon observation Fourier-transform spectrometer on the Greenhouse Gases Observing Satellite for greenhouse gases monitoring, Appl. Opt., 48, 6716-6733, 2009.

Kuze, A., Suto, H., Shiomi, K., Kawakami, S., Tanaka, M., Ueda, Y., Deguchi, A., Yoshida, J., Yamamoto, Y., Kataoka, F., Taylor, T. E., and Buijs, H. L.: Update on GOSAT TANSO-FTS performance, operations, and data products after more than 6 years in space, Atmos. Meas. Tech., 9, 2445-2461, doi:10.5194/amt-92445-2016, 2016. 
Maasakkers, J. D., Jacob, D. J., Sulprizio, M. P., Turner, A. J., Weitz, M., Wirth, T., Hight, C., DeFigueiredo, M., Desai, M., Schmeltz, R., Hockstad, L., Bloom, A. A., Bowman, K. W., Jeong, S., and Fischer, M. L.: Gridded National Inventory of US Methane Emissions, Environ. Sci. Technol., 50, 13123-13133, doi:10.1021/acs.est.6b02878, 2016.

Miller, S. M. and Michalak, A. M.: Constraining sector-specific $\mathrm{CO}_{2}$ and $\mathrm{CH}_{4}$ emissions in the US, Atmos. Chem. Phys., 17, 3963-3985, doi:10.5194/acp-17-3963-2017, 2017.

Monteil, G., Houweling, S., Butz, A., Guerlet, S., Schepers, D., Hasekamp, O., Frankenberg, C., Scheepmaker, R., Aben, I., and Röckmann, T.: Comparison of $\mathrm{CH}_{4}$ inversions based on 15 months of GOSAT and SCIAMACHY observations, J. Geophy. Res., 118, 11807-11823, doi:10.1002/2013JD019760, 2013.

Nisbet, E., Dlugokencky, E., and Bousquet, P.: Methane on the rise - again, Science, 343, 493-495, doi:10.1126/science.1247828, 2014.

Parker, R., Boesch, H., Cogan, A., Fraser, A., Feng, L, Palmer, P., Messerschmidt, J., Deutscher, N., Griffth, D., Notholt, J., Wennberg, P., and Wunch, D.: Methane Observations from the Greenhouse gases Observing SATellite: Comparison to groundbased TCCON data and Model Calculations, Geophys. Res. Lett., 38, L15807, doi:10.1029/2011GL047871, 2011.

Parker, R. J., Boesch, H., Byckling, K., Webb, A. J., Palmer, P. I., Feng, L., Bergamaschi, P., Chevallier, F., Notholt, J., Deutscher, N., Warneke, T., Hase, F., Sussmann, R., Kawakami, S., Kivi, R., Griffith, D. W. T., and Velazco, V.: Assessing 5 years of GOSAT Proxy $\mathrm{XCH}_{4}$ data and associated uncertainties, Atmos. Meas. Tech., 8, 4785-4801, doi:10.5194/amt-8-4785-2015, 2015.

Pillai, D., Buchwitz, M., Gerbig, C., Koch, T., Reuter, M., Bovensmann, H., Marshall, J., and Burrows, J. P.: Tracking city $\mathrm{CO}_{2}$ emissions from space using a high resolution inverse modeling approach: A case study for Berlin, Germany, Atmos. Chem. Phys., 16, 9591-9610, doi:10.5194/acp-16-9591-2016, 2016.

Rigby, M., Prinn, R. G., Fraser, P. J., Simmonds, P. G., Langenfelds, R. L., Huang, J., Cunnold, D. M., Steele, L. P., Krummel, P. B., Weiss, R. F., O’Doherty, S., Salameh, P. K., Wang, H. J., Harth, C. M., Mühle, J., and Porter, L. W.: Renewed growth of atmospheric methane, Geophys. Res. Lett., 35, L22805, doi:10.1029/2008GL036037, 2008.

Rodgers, C. D.: Inverse Methods for Atmospheric Sounding: Theory and Practice, World Scientific Publishing, 2000.

Schaefer, H., Mikaloff Fletcher, S. E., Veidt, C., Lassey, K. R., Brailsford, G. W., Bromley, T. M., Dlugokencky, E. J., Michel, S. E., Miller, J. B., Levin, I., Lowe, D. C., Martin, R. J., Vaughn, B. H., and White, J. W. C.: A 21st-century shift from fossil-fuel to biogenic methane emissions indicated by ${ }^{13} \mathrm{CH}_{4}$, Science, 352, 80-84, doi:10.1126/science.aad2705, 2016.

Schepers, D., Guerlet, S., Butz, A., Landgraf, J., Frankenberg, C., Hasekamp, O., Blavier, J.-F., Deutscher, N. M., Griffith, D. W. T., Hase, F., Kyro, E., Morino, I., Sherlock, V., Sussmann, R., and Aben, I.: Methane retrievals from Greenhouse Gases Observing Satellite (GOSAT) shortwave infrared measurements: Performance comparison of proxy and physics retrieval algorithms, J. Geophys. Res., 117, D10307, doi:10.1029/2012JD017549, 2012.

Schneising, O., Buchwitz, M., Reuter, M., Heymann, J., Bovensmann, H., and Burrows, J. P.: Long-term analysis of carbon dioxide and methane column-averaged mole fractions re- trieved from SCIAMACHY, Atmos. Chem. Phys., 11, 2863 2880, doi:10.5194/acp-11-2863-2011, 2011.

Schneising, O., Bergamaschi, P., Bovensmann, H., Buchwitz, M., Burrows, J. P., Deutscher, N. M., Griffith, D. W. T., Heymann, J., Macatangay, R., Messerschmidt, J., Notholt, J., Rettinger, M., Reuter, M., Sussmann, R., Velazco, V. A., Warneke, T., Wennberg, P. O., and Wunch, D.: Atmospheric greenhouse gases retrieved from SCIAMACHY: comparison to ground-based FTS measurements and model results, Atmos. Chem. Phys., 12, 1527-1540, doi:10.5194/acp-12-1527-2012, 2012.

Schneising, O., Heymann, J., Buchwitz, M., Reuter, M., Bovensmann, H., and Burrows, J. P.: Anthropogenic carbon dioxide source areas observed from space: assessment of regional enhancements and trends, Atmos. Chem. Phys., 13, 2445-2454, doi:10.5194/acp-13-2445-2013, 2013.

Schneising, O., Burrows, J. P., Dickerson, R. R., Buchwitz, M. Reuter, M., and Bovensmann, H.: Remote sensing of fugitive methane emissions from oil and gas production in North American tight geologic formations, Earth's Future, 2, 548-558, doi:10.1002/2014EF000265, 2014.

Turner, A. J., Jacob, D. J., Wecht, K. J., Maasakkers, J. D., Biraud, S. C., Boesch, H., Bowman, K. W., Deutscher, N. M., Dubey, M. K., Griffith, D. W. T., Hase, F., Kuze, A., Notholt, J., Ohyama, H., Parker, R., Payne, V. H., Sussmann, R., Velazco, V. A., Warneke, T., Wennberg, P. O., and Wunch, D.: Estimating global and North American methane emissions with high spatial resolution using GOSAT satellite data, Atmos. Chem. Phys., 15, 7049-7069, doi:10.5194/acp-15-7049-2015, 2015.

Turner, A. J., Jacob, D. J., Benmergui, J., Wofsy, S. C., Maasakkers, J. D., Butz, A., Hasekamp, O., and Biraud, S. C.: A large increase in US methane emissions over the past decade inferred from satellite data and surface observations, Geophys. Res. Lett., 43, 2218-2224, doi:10.1002/2016GL067987, 2016.

Veefkind, J. P., Aben, I., McMullan, K., Förster, H., De Vries, J., Otter, G., Claas, J., Eskes, H. J., De Haan, J. F., Kleipool, Q., Van Weele, M., Hasekamp, O., Hoogeveen, R., Landgraf, J., Snel, R., Tol, P.,Ingmann, P., Voors, R., Kruizinga, B., Vink, R., Visser, H., and Levelt, P. F.: TROPOMI on the ESA Sentinel-5 Precursor: A GMES mission for global observations of the atmospheric composition for climate, air quality and ozone layer applications, Rem. Sens. Environ., 120, 70-83, 2012.

Velazco, V. A., Buchwitz, M., Bovensmann, H., Reuter, M., Schneising, O., Heymann, J., Krings, T., Gerilowski, K., and Burrows, J. P.: Towards space based verification of $\mathrm{CO}_{2}$ emissions from strong localized sources: fossil fuel power plant emissions as seen by a CarbonSat constellation, Atmos. Meas. Tech., 4, 2809-2822, doi:10.5194/amt-4-2809-2011, 2011.

Wecht, K. J., Jacob, D. J., Frankenberg, C., Jiang, Z., and Blake, D. R.: Mapping of North American methane emissions with high spatial resolution by inversion of SCIAMACHY satellite data, J. Geophys. Res. Atmos., 119, 77417756, doi:10.1002/2014JD021551, 2014a.

Wecht, K. J, Jacob, D. J., Sulprizio, M. P., Santoni, G. W., Wofsy, S. C., Parker, R., Bösch, H., and Worden, J.: Spatially resolving methane emissions in California: constraints from the CalNex aircraft campaign and from present (GOSAT, TES) and future (TROPOMI, geostationary) satellite observations, Atmos. Chem. Phys., 14, 8173-8184, doi:10.5194/acp-14-8173-2014, 2014 b. 
Wunch, D., Toon, G. C., Blavier, J.-F. L., Washenfelder, R. A., Notholt, J., Connor, B. J., Griffith, D. W. T., Sherlock, V., and Wennberg, P. O.: The Total Carbon Column Observing Network, Phil. Trans. R. Soc. A, 369, 2087-2112, doi:10.1098/rsta.2010.0240, 2011.

Wunch, D., Toon, G. C., Sherlock, V., Deutscher, N. M, Liu, X., Feist, D. G., and Wennberg, P. O.: The Total Carbon Column Observing Network's GGG2014 Data Version. Carbon Dioxide Information Analysis Center, Oak Ridge National Laboratory, Oak Ridge, Tennessee, USA, doi:10.14291/tccon.ggg2014.documentation.R0/1221662,

2015.
Yoshida, Y., Kikuchi, N., Morino, I., Uchino, O., Oshchepkov, S., Bril, A., Saeki, T., Schutgens, N., Toon, G. C., Wunch, D., Roehl, C. M., Wennberg, P. O., Griffith, D. W. T, Deutscher, N. M., Warneke, T., Notholt, J., Robinson, J., Sherlock, V., Connor, B., Rettinger, M., Sussmann, R., Ahonen, P., Heikkinen, P., Kyrö, E., Mendonca, J., Strong, K., Hase, F., Dohe, S., and Yokota, T.: Improvement of the retrieval algorithm for GOSAT SWIR $\mathrm{XCO}_{2}$ and $\mathrm{XCH}_{4}$ and their validation using TCCON data, Atmos. Meas. Tech., 6, 1533-1547, doi:10.5194/amt-6-1533-2013, 2013. 